\title{
CRA Special Lending Programs
}

Robert B. Avery, Raphael W. Bostic, and Glenn B. Canner, of the Board's Division of Research and Statistics, prepared this article.

Increasing the flow of credit to lower-income households and communities has been the focus of many public-sector programs, such as those of the Federal Housing Administration and the Rural Housing Service. Government regulation of private-sector activities is often used to bolster such lending. The most prominent example of the latter approach is the Community Reinvestment Act (CRA). The CRA was enacted in 1977 to encourage federally insured banking institutions (commercial banks and savings associations) to help meet the credit needs of their communities, including those of lower-income areas, in a manner consistent with their safe and sound operation.

In responding to the CRA, banking institutions have sought to expand lending to lower-income populations in a variety of ways, but the approaches can be sorted into two broad types, both typically involving special marketing and outreach. In one approach, lenders have sought CRA-related customers who would qualify for market-priced loans under traditional standards (underwriting guidelines) for creditworthiness. In the second type of effort, lenders have sought customers by modifying their underwriting guidelines or loan pricing.

To expand lending to lower-income populations through either approach, many banking institutions have developed or joined "CRA special lending programs," which seek out and assist such borrowers in a variety of ways. These programs vary greatly across banking institutions, differ widely in terms of their characteristics and how they are implemented, and can often be an important element of a banking institution's CRA-related lending activities. Although many institutions have offered special lending programs, some for many years, little systematic information is available about them. To further the understanding of these CRA special lending programs, this article provides new information on the nature of these programs, with particular emphasis placed on their characteristics and how these characteristics relate to the performance (delinquency and default rates) and profitability of the loans extended through them.

\section{BACKGROUND}

The CRA was enacted in response to concerns that banking institutions were, in some instances, failing to adequately seek out and help meet the credit needs of viable lending prospects in all sections of their communities. It directs the federal regulators of banking institutions (the Board of Governors of the Federal Reserve System, the Federal Deposit Insurance Corporation, the Office of the Comptroller of the Currency, and the Office of Thrift Supervision) to encourage the federally insured institutions they regulate to help meet community credit needs in a manner consistent with safe and sound operations.

The CRA is likely to influence the behavior of a banking institution primarily through two mechanisms: an examination and ratings system and the formation of public opinion. Under the examinations and ratings system, regulators periodically visit the institution to assess the degree to which its lending is adequately serving its entire community. The CRA regulations guiding these examinations-jointly issued by the four federal banking agenciesemphasize an institution's record of serving the credit needs of low- and moderate-income populations within its CRA assessment area (see box "The CRA Regulations"). Each examination is followed by the assignment of a rating that is based on both quantitative and qualitative measures of the institution's performance.

An important aspect of the examination and ratings system is the statutory provision that requires regulators to consider the record of a banking institution in meeting the goals of the act when deciding on applications from that institution. In considering an application from an institution with a performance problem under the CRA, the regulators can-depending on the degree of the problem-potentially deny the application or require the institution to meet certain conditions in order to obtain approval.

A second mechanism by which the CRA can influence the behavior of banking institutions is through the force of public opinion. In August 1989 the Congress amended the CRA to require each banking institution to allow public inspection of its examination ratings and supporting written evaluation. Such disclosure can influence the relationships that banking institutions have with potential investors, deposi- 
tors, and borrowers. It may, for example, influence the nature and extent of public comments received on an application for a merger or acquisition. It may also influence decisions made by potential depositors, who may direct their funds to those institutions with the highest CRA performance ratings.

Banking institutions thus have incentives to respond to the CRA. First, banking institutions have an incentive to engage in CRA-related activities to enhance their CRA performance rating. In addition, they have an interest in maintaining a good public image, which may be supported by a good CRA performance rating or by other CRA-related activities. Moreover, because of the potentially important role that CRA performance ratings and public com- ments can play in applications, such as for mergers and acquisitions, those banking institutions that anticipate making such applications are likely to be particularly sensitive to CRA considerations.

In spite of a wealth of experience by banking institutions in undertaking CRA-related lending activities, little systematic information has been publicly available about those activities. For example, while banking institutions are known to use third parties to help reach certain targeted populations, little information is available on the nature and prevalence of these relationships.

Also, there is reason to believe that the overall performance and profitability of CRA-related loans may differ from those of loans extended to other

\section{The CRA Regulations}

The regulations that implement the CRA set forth three tests by which the performance of most large retail banking institutions is evaluated: an investment test, a service test, and a lending test.

The investment test considers a banking institution's qualified investments that benefit the institution's assessment area or a broader statewide or regional area that includes its assessment area. ${ }^{1}$ A qualified investment is a lawful investment, deposit, membership share, or grant that has community development as its primary purpose.

The service test considers the availability of an institution's system for delivering retail banking services and judges the extent of its community development services and their degree of innovativeness and responsiveness. Among the assessment criteria for retail banking services are the geographic distribution of an institution's branches and the availability and effectiveness of alternative systems for delivering retail banking services, such as automated teller machines, in low- and moderate-income areas and to low- and moderate-income persons.

The lending test involves the measurement of lending activity for a variety of loan types, including home mortgage, small business, and small farm loans. Among the assessment criteria are the geographic distribution of lending, the distribution of lending across different types of borrowers, the extent of community development lending, and the use of innovative or flexible lending practices to address the credit needs of low- or moderate-income individuals or areas.

1. For purposes of evaluating CRA performance, each institution must delineate the geographic areas that constitute its CRA assessment area. For a retail-oriented banking institution, the institution's CRA assessment area must include the areas in which the institution operates branches and deposittaking automated teller machines and any surrounding areas in which it originated or purchased a substantial portion of its loans. For a more complete description of these issues, see 12 CFR 228.41.
For the lending test, the regulations implementing the CRA require the federal banking regulatory agencies to evaluate the geographic distribution of a banking institution's lending in two ways: (1) the proportion of all the institution's loans that are extended within its assessment area and (2) for loans within the institution's assessment area, their distribution across neighborhoods of differing incomes. In the latter measure, lending in low- and moderate-income neighborhoods is weighted heavily in CRA performance evaluations. ${ }^{2}$

The CRA regulations also require the banking agencies to evaluate the distribution of a banking institution's lending within its assessment area across borrowers of different economic standing. This provision was added as part of revisions made to the CRA regulations in 1995. The exact definition of economic standing varies with the loan product being examined. For residential mortgage lending products, CRA assessments consider the distribution of loans across low-, moderate-, middle-, and upper-income borrowers, with a special focus on lending to low- and moderateincome borrowers. ${ }^{3}$ For small business lending products, assessments consider the distribution of small loans (loans of $\$ 1$ million or less) across businesses with differing levels of revenue, with a particular focus on loans to firms with annual revenues of $\$ 1$ million or less.

2. The distribution of loans by neighborhood income is assessed for four income groups: low, moderate, middle, and upper. In a low-income area (typically a census tract), the median family income is less than 50 percent of the median family income for the broader area (such as a metropolitan statistical area or the nonmetropolitan portion of a state) as measured in the most recent decennial census. In a moderate-income area, the median family income is at least 50 percent and less than 80 percent of that for the broader area. In a middle-income area, the percentage ranges from at least 80 percent to less than 120 percent. And in an upper-income area, the percentage is at least 120 percent.

3. Borrower income categories follow the same groupings as those for neighborhoods but rely on the borrower's income relative to that of the concurrently measured median family income of the broader area (metropolitan statistical area or nonmetropolitan portion of the state). 
customers. The costs and possibly lowered revenues resulting from special marketing and outreach and from modified underwriting or loan pricing may make CRA-related loans less profitable than other loans.

Moreover, the performance and profitability of CRA-related loans, whether or not they were originated through extra efforts or nontraditional standards, may differ from those of non-CRA-related loans simply because the two loan groups have differing characteristics. CRA-related loans might, for example, be smaller on average than other loans, which would make them relatively costly to originate and administer, or they might be less likely than other loans to be prepaid, a tendency that would also affect their profitability. ${ }^{1}$ Despite widespread interest in the topic, little has been known about the performance and profitability of the loans that are made in conformity with the CRA regulation.

To learn more about CRA-related lending activities, the Congress in November 1999 asked the Board of Governors of the Federal Reserve System to conduct a comprehensive study of the issue. ${ }^{2}$ To this end, the Board conducted a special survey of the largest retail banking institutions to collect information on their lending experiences (see box "Participation in the Survey"). ${ }^{3}$ The survey was in two parts. Part A focused on an institution's total lending and its CRArelated lending in four broad loan product categories: one- to four-family home purchase and refinance lending, one- to four-family home improvement lending, small business lending, and community development lending.

In part B, the survey gathered extensive information on CRA special lending programs, defined as programs that banking institutions have established (or participate in) specifically to enhance their CRA performance, even if these programs may have been established for other reasons as well. Because these programs are often an important element of a banking institution's overall efforts to comply with the CRA, the survey collected information on many of their characteristics, including the performance and profitability of the lending extended under the programs.

1. Lower-income homeowners may have lower rates of mobility than other homeowners and consequently a reduced propensity to prepay their home purchase loans. The reduced propensity would increase the value of the loan to the lender during periods of falling interest rates but decrease it when interest rates are rising.

2. Section 713 of the Gramm-Leach-Bliley Act of 1999 (P.L. No. 106-95).

3. A report summarizing the major findings of the survey was submitted to the Congress and made available to the public on July 17 , 2000. The report and the survey questionnaire are available on the Federal Reserve Board's web site, at www.federalreserve.gov/ boarddocs/surveys/CRAloansurvey.
Responses to part B of the survey provide the data that form the basis of the analysis presented in this article. The analysis focuses primarily on CRA special lending programs exclusively offering home purchase and refinance loans, as survey responses indicated that most special lending programs were of this type.

\section{SURVEY RESPONSES REGARDING CRA SPECIAL LENDING PROGRAMS}

The Federal Reserve Board survey is the first systematic collection of information on the characteristics, performance, and profitability of CRA special lending programs from a broad base of institutions. As such, it provides a unique opportunity to learn about the characteristics of CRA special lending programs and relate these characteristics to the performance and profitability of programs.

\section{Participation in the Survey}

Participation by banking institutions in the Federal Reserve Board's Survey of the Performance and Profitability of CRA-Related Lending was voluntary. On January 21,2000 , each prospective respondent was mailed a copy of the questionnaire accompanied by a cover letter from Federal Reserve Board Chairman Alan Greenspan explaining the purpose of the survey and seeking voluntary cooperation in the study. The sample of institutions selected to participate in the survey consisted of roughly the largest 500 retail banking institutions - 400 commercial banks and 100 savings associations. The sample was limited to the largest banking institutions because they account for the vast majority (estimated at more than 70 percent) of CRA-related lending nationwide. Survey responses were received from 143 banking institutions114 commercial banks and 29 savings associations. Despite their relatively small number, the 143 survey respondents accounted for about one-half of the assets of the more than 10,000 U.S. banking institutions in existence as of December 31, 1999.

Response rates varied markedly by the asset size of the institution. More than 80 percent of the largest surveyed banking institutions (assets of $\$ 30$ billion or more as of December 31, 1999) returned a survey (27 out of 33 sampled institutions in this asset category). In contrast, only about 19 percent (72 out of 363) of the smallest surveyed banking institutions (assets of between $\$ 0.950$ billion and $\$ 4.999$ billion) responded. Institutions with assets of between $\$ 5$ billion and $\$ 29.999$ billion had a response rate of about 40 percent. 
In the survey, banking institutions were asked to provide detailed information on the 1999 activity of their CRA special lending programs, defined as any housing-related, small business, consumer, or other type of lending program that the institution uses specifically to enhance its CRA performance. ${ }^{4}$ For the survey, CRA special lending programs could include special programs offered or developed in conjunction with third parties, such as lending consortiums, nonprofit organizations, or government agencies that offer special lending programs in which an institution participates. ${ }^{5}$

The survey was sent to the 500 largest retail banking institutions in existence at the end of 1999400 commercial banks and 100 savings associations.

\footnotetext{
4. A program would meet this definition only if one of the program's documented purposes was to enhance the institution's CRA performance.

5. However, traditional government-backed lending programs, such as those offered by the Federal Housing Administration, the Department of Veterans Affairs, and the Small Business Administration, were not considered to be CRA special lending programs for the purposes of the survey unless an institution provided a special enhancement, such as credit counseling, a homebuyer education program, or a waiver or reduction of loan fees.
}

Of these, 143 institutions responded (table 1). ${ }^{6}$ Respondents offered or participated in 622 CRA special lending programs in 1999. Seventy-three percent of the responding institutions offered at least 1 CRA special lending program; on average the institutions with programs offered about 6 programs. To limit the burden of responding to the survey, the survey sought detailed information on only the 5 largest of a banking institution's CRA special lending programs (measured by dollar volume of originations in 1999), a restriction that produced detailed information for 341 programs. These 341 programs are estimated to account for 91 percent of the loan dollars that responding institutions extended under CRA special lending programs in 1999.

CRA special lending programs are often complex in design and can involve many features and a diverse

6. One of these institutions did not answer any questions in the special lending portion of the survey and is excluded from the tables. Respondent institutions are grouped into three asset-size categories: $\$ 0.950$ billion to $\$ 4.999$ billion; $\$ 5$ billion to $\$ 29.999$ billion; and $\$ 30$ billion or more. Institutions in the first two categories together (assets of $\$ 0.950$ billion to $\$ 29.999$ billion) will be referred to below as "smaller" institutions, and those with assets of $\$ 30$ billion or more will be referred to as "large."

1. Banking institutions and CRA special lending programs covered in survey, by size of institution, 1999

\begin{tabular}{|c|c|c|c|c|}
\hline \multirow{2}{*}{ Item } & \multirow{2}{*}{$\begin{array}{l}\text { All reporting } \\
\text { institutions }\end{array}$} & \multicolumn{3}{|c|}{ Size of banking institution (assets, in millions of dollars) } \\
\hline & & $950-4,999$ & $5,000-29,999$ & 30,000 or mor \\
\hline \multicolumn{5}{|l|}{ Institutions } \\
\hline Number responding to survey ${ }^{1}$ & 142 & 72 & 43 & 27 \\
\hline \multicolumn{5}{|l|}{ Offering at least one program } \\
\hline Number $\ldots \ldots \ldots \ldots \ldots \ldots$ & 103 & 48 & 31 & 24 \\
\hline Percent $\ldots \ldots \ldots \ldots \ldots \ldots$ & 73 & 67 & 72 & 89 \\
\hline \multicolumn{5}{|l|}{ Number of programs } \\
\hline Among the five largest at each institution ${ }^{2} \ldots$. & 341 & 138 & 116 & 87 \\
\hline Smaller than the five largest at each institution . & 281 & 31 & 139 & 111 \\
\hline \multicolumn{5}{|l|}{$\begin{array}{l}\text { Total } \\
\text { The }\end{array}$} \\
\hline 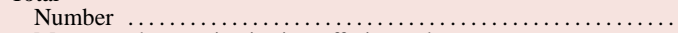 & 622 & 169 & 255 & 198 \\
\hline Mean number per institution offering at least one program ... & 6.0 & 3.5 & 8.2 & 8.3 \\
\hline \multicolumn{5}{|l|}{$\begin{array}{l}\text { Number of programs among the five largest at each institution, } \\
\text { by type of loan offered }\end{array}$} \\
\hline One- to four-family home, purchase and refinance only ${ }^{3} \ldots \ldots$. & 247 & 98 & 83 & 66 \\
\hline 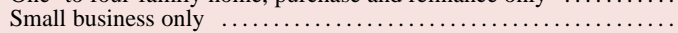 & 27 & 17 & 4 & 6 \\
\hline Other & 67 & 23 & 29 & 15 \\
\hline One- to four-family home, home improvement only & 17 & 7 & 6 & 4 \\
\hline Multifamily only $\ldots \ldots \ldots \ldots \ldots \ldots \ldots \ldots \ldots \ldots \ldots \ldots$ & 16 & 6 & 8 & 2 \\
\hline Consumer only .......... & 5 & 1 & 3 & 1 \\
\hline Commercial only ........... & 4 & 1 & 3 & 0 \\
\hline Other $^{4} \ldots \ldots \ldots \ldots \ldots \ldots \ldots \ldots \ldots \ldots \ldots \ldots \ldots \ldots$ & 25 & 8 & 9 & 8 \\
\hline \multicolumn{5}{|l|}{$\begin{array}{l}\text { Programs among the five largest at each institution } \\
\text { operated by a distinct unit or department of institution }\end{array}$} \\
\hline Percentage of institutions among those with programs . & 67 & 60 & 77 & 92 \\
\hline Percentage of programs among the five largest ....... & 63 & 56 & 75 & 80 \\
\hline \multicolumn{5}{|c|}{$\begin{array}{l}\text { 1. Excludes one institution (in the middle size category) that did not respond } \\
\text { the special lending portion of the survey. For more information on the sample } \\
\text { ze, see text box "Participation in the Survey." } \\
\text { 2. Institutions were asked for detailed information on only the five largest of }\end{array}$} \\
\hline
\end{tabular}

their programs (measured by dollar volume of 1999 originations).

3. Programs reported in this row and the remaining rows of this table are from among the 341 reported by all institutions to be among their 5 largest. Data 
group of market participants. As a consequence, the operation of some of these programs requires considerable training and experience. To facilitate the efficient implementation of these programs, many banking institutions establish distinct units or departments within the institution to run their CRA special lending programs. Among the banking institutions that offered at least one special lending program, 67 percent had at least one program operated by a distinct unit or department (table 1). Larger banking institutions in the sample were more likely than smaller institutions to offer programs through a distinct unit or department. Overall, of the special programs that each institution reported to be among its five largest, 63 percent were operated by a distinct unit or department.

Before the survey was conducted, CRA special lending programs had been known to involve a range of credit products, but no information was available on the incidence of special lending programs across loan product categories. Results of the survey revealed that 72 percent of the programs (and 89 percent of the program dollars originated in 1999) for which banking institutions provided detailed information focused on one- to four-family home purchase and refinance loans. The next largest category of CRA special lending programs, comprising 8 percent of reported programs, focused on small business loans. The remaining programs cover a variety of loan products, none of which individually accounted for a substantial proportion of all programs.

Because CRA special lending programs concentrating on home purchase and refinance loans constitute most of the CRA programs reported in the survey, the analysis in the remainder of this article (covering the data in table 2 and subsequent tables) focuses exclusively on these programs. The relatively small number of programs that were reported to focus on small business and other lending products precludes a comprehensive analysis of them. For simplicity, we will hereafter usually refer to CRA special lending programs that focus on home purchase and refinance loans as "CRA special mortgage programs."

\section{THE CHARACTERISTICS OF CRA SPECIAL MORTGAGE PROGRAMS}

The survey was designed to collect information that would shed light on the diversity of characteristics, both within and across banking institutions, among CRA special lending programs. In addition, because it was recognized that banking institutions may have established these programs for a variety of reasons that go beyond their efforts to enhance their CRA performance, the survey asked respondents to provide information on both the reasons for which they originally adopted these programs and the current benefits they receive from the programs.

In table 1, data in the "all reporting institutions" column were taken from the 142 institutions responding to part B of the survey. In the analysis that follows (covering data reported in table 2 and subsequent tables), figures in the "all-institutions estimate" column are also based on the responses of the 142 institutions, but these responses have been weighted so that the figures represent an estimate of what the responses would have been if all 500 institutions had responded to the survey and provided answers to all applicable questions (see box "Calculating the 'All Institutions Estimate"”).

\section{The Size and Age of Individual Programs}

Survey responses indicate that in 1999 the dollar amount of loans extended under all CRA special lending programs made up a relatively small portion of total CRA-related lending in that year for most reporting institutions (see box "Survey Definition of a CRA-Related Loan"). In the case of home purchase and refinance loans, the proportion of CRA-related home purchase and refinance loan dollars that were extended under CRA special mortgage programs was only 4 percent for the median banking institution. Among the institutions that had CRA special mortgage programs, the proportion was 18 percent for the median institution. For about one-sixth of all institutions in the survey, however, CRA special mortgage programs accounted for more than 40 percent of their CRA-related home purchase and refinance loan dollars (data not shown in tables). ${ }^{7}$

In the aggregate, CRA special mortgage programs made up 21 percent of the total dollars of CRA-related home purchase and refinance loans originated by reporting institutions (and only 3 percent of the total dollars of home purchase and refinance originations). ${ }^{8}$

Information reported also suggests that individual CRA special mortgage programs are generally small. For 1999, an estimated 31 percent of the CRA special mortgage programs reported in the survey had total

7. The proportions of lending for home improvement and small business that were conducted through CRA special lending programs were much lower than for home purchase or refinance.

8. Estimates are derived from responses to questions in part A of the survey. 
originations of $\$ 500,000$ or less, and about 28 percent had total originations of between $\$ 500,000$ and $\$ 2$ million; only 18 percent had originations of more than $\$ 15$ million (table 2).

The size of CRA special mortgage programs varied with the asset size of the banking institution, as programs tended to be larger for the largest banks in the survey (data not shown in tables). The median size of CRA special mortgage programs for large banks (those with assets of $\$ 30$ billion or more) was about $\$ 36$ million; for the smallest banks in the sample (those with assets of $\$ 0.950$ billion to $\$ 4.999$ billion) the median size of CRA special mortgage programs was about $\$ 680,000$.

Most of the CRA special mortgage programs that were reported in the survey were established relatively recently. More than half (62 percent) were established after the CRA regulations were modified in 1995 (table 2); only 6 percent of the programs were established before 1990 . This pattern is consistent with the small size of many programs, as newer programs tended to be smaller.

\section{Reasons for Establishing CRA Special Mortgage Programs and Current Benefits}

Banking institutions cite many reasons for originally establishing or participating in CRA special mortgage programs (table 3 ). Responding to the credit needs of the local community and promoting community growth and stability are the two most frequently cited reasons. The third most frequently cited reason (for 76 percent of these programs) was to obtain a "Satisfactory" or "Outstanding" CRA rating. However, only 1 percent of CRA special mortgage programs are reported to have been established only to obtain a satisfactory or outstanding CRA rating. The fourth most frequently cited reason (also mentioned for more than half the programs) was to improve the institution's public image.

The pattern of reasons for establishing programs does not vary greatly by size of reporting institution in most cases; but large banking institutions were more likely than smaller institutions to cite a desire to improve their public image, to maintain their market

\section{Calculating the "All-Institutions Estimate"}

The appropriateness of the "all-institutions estimate," reported in table 2 and subsequent tables, relies upon the validity of the assumptions needed to construct it. Key assumptions are those related to the treatment of sample and question nonresponse. The proportion of banking institutions that responded to the survey varied significantly by asset-size group (see preceding box "Participation in the Survey"); as a consequence, unless behavior is the same for institutions across different asset-size categories, simple averages based on the answers provided by respondents will distort the picture of what the survey responses would have been if all 500 institutions had provided answers to all applicable questions.

To address this concern, the data in the "all-institutions estimate" column are calculated, in part, on the basis of adjustment factors reflecting the relative response rates for respondents in the three asset-size classes. The sample response adjustment factor for respondents with assets of $\$ 30$ billion or more is 1.2 (or $33 \div 27$ ), that is, of the 33 institutions in the category, 27 responded). Similarly, the sample response adjustment factor for respondents with assets of $\$ 5$ billion to $\$ 29.999$ billion is 2.4 (or $104 \div 44)$; and for respondents with assets of $\$ 0.950$ billion to $\$ 4.999$ billion, the adjustment factor is 5.0 (or $363 \div 72$ ). ${ }^{1}$

1. This procedure assumes that the respondents within an asset-size category are representative of all institutions in that category.
An additional adjustment problem in calculating responses for the all-institutions estimate arises from the fact that some questions were not answered by a significant proportion of respondents. For questions with a significant number of nonresponses (tables 7-11), an additional adjustment factor, also based on asset size, was applied to correct for the varying propensities within the asset-size classes to answer questions.

The general procedure used to calculate questionresponse adjustment factors was to assume that respondents within an asset-size category that did not provide an answer to a question would have the same response pattern as those that did. Thus, the number of respondents who answered each question was scaled up to represent those who did not answer. Respondents for whom a question was not applicable were not used in calculating the all-institutions estimates. For example, if 24 respondents were asked a question and 12 provided an answer, each of the 12 was multiplied by 2 to represent a total of 24 institutions. Question-response adjustment factors were calculated separately for each asset-size category because the responses varied by asset size.

Data in the all-institutions estimate column in tables 7-11 are computed with the question-response adjustments in conjunction with the sample-response adjustments. For example, if the 12 respondents in the example above were large institutions, the total response adjustment for each of the 12 institutions that provided an answer would be $2 \times(33$ $\div 27$ ), or 2.44 . 
2. CRA special mortgage programs, grouped by size of banking institution and distributed by size and age of program, 1999 Percentage of programs

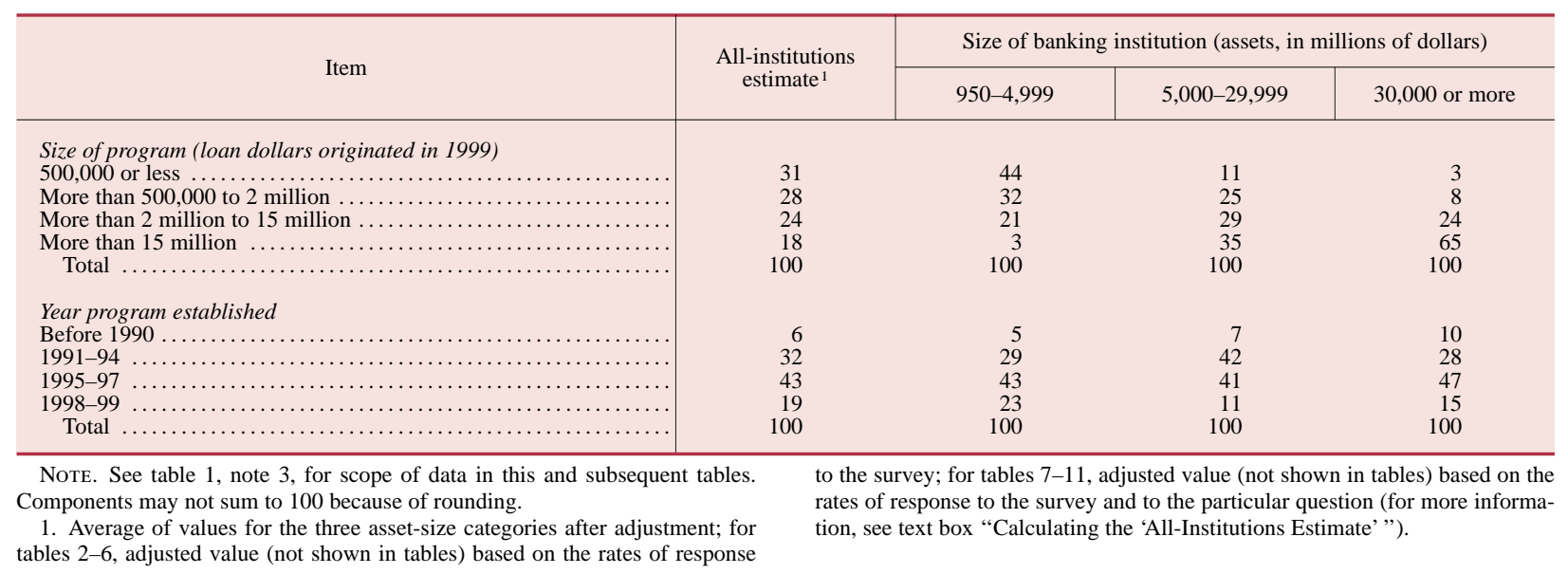

share of lending, and to minimize the likelihood of adverse public comment on their CRA record.

That only about three-fourths of CRA special mortgage programs were reportedly established to achieve a satisfactory or outstanding CRA rating may be somewhat puzzling, given that the survey explicitly asked institutions to report only on special lending programs that had as one of their documented purposes enhancement of the institution's CRA performance. One possibility is that some of the programs that support the CRA-related lending activities of institutions are not considered by the institutions to be "needed" to obtain a particular CRA rating. A second possibility is that the support of CRA-related activities is a documented purpose of some programs, but a relatively minor one.

Banking institutions reported receiving a variety of current benefits from offering or participating in CRA

\section{Survey Definition of a CRA-Related Loan}

In conducting the study of the performance and profitability of loans made in conformity with the CRA, the Board used the current CRA regulations as a guide in establishing a definition of a "CRA-related loan." As noted, the regulations require the banking agencies to evaluate the geographic distribution of lending and the distribution of lending across borrowers of different economic standing (see box "The CRA Regulations"). As a result, for purchase and refinance lending on one- to four-family homes, a CRA-related loan was defined to mean any loan made within the banking institution's CRA assessment area to a low- or moderate-income borrower (regardless of neighborhood income) or in a low- or moderate-income neighborhood (regardless of borrower income). special mortgage programs. Obtaining either a satisfactory or outstanding CRA rating was, again, the third most frequently mentioned benefit (for 80 percent of the programs), but also as before, this was cited as the only current benefit for just 1 percent of the programs. Responding to the credit needs of the local community, promoting community growth and stability, and improving the public image of the institution are also frequently cited current benefits of these CRA special lending programs.

\section{Features of CRA Special Mortgage Programs}

Almost all CRA special mortgage programs were targeted to populations that are emphasized in the CRA regulations: lower-income borrowers and borrowers in lower-income neighborhoods. Most programs targeted both of these populations (table 4). When only one population was targeted, it was much more likely to be lower-income borrowers than lower-income neighborhoods.

Third parties played a role in about three-fourths of CRA special mortgage programs (table 5). Third parties involved in the programs included public entities at all levels of government and a range of forprofit and nonprofit private-sector firms and organizations. Some programs (31 percent in the survey, not shown in tables) involved the active participation of multiple third parties. ${ }^{9}$

9. Programs at large banking institutions were more likely than those at smaller institutions to involve multiple third parties. Therefore the percentages shown in table 5 for each type of entity are larger for large institutions than for smaller institutions even though the likelihood of participation by any third party is about the same. 
3. Reasons for establishing CRA special mortgage programs and their current benefits to the banking institution, by size of institution, 1999

Percentage of programs

\begin{tabular}{|c|c|c|c|c|}
\hline \multirow{2}{*}{ Item } & \multirow{2}{*}{$\begin{array}{l}\text { All-institutions } \\
\text { estimate }\end{array}$} & \multicolumn{3}{|c|}{ Size of banking institution (assets, in millions of dollars) } \\
\hline & & $950-4,999$ & $5,000-29,999$ & 30,000 or more \\
\hline 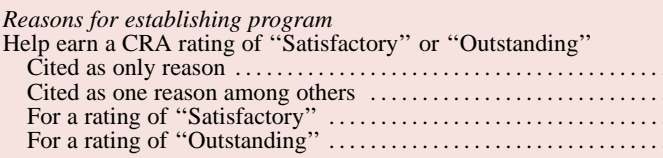 & $\begin{array}{l}1 \\
76 \\
37 \\
52\end{array}$ & $\begin{array}{r}1 \\
74 \\
40 \\
42\end{array}$ & $\begin{array}{r}0 \\
86 \\
35 \\
75\end{array}$ & $\begin{array}{r}2 \\
68 \\
21 \\
59\end{array}$ \\
\hline 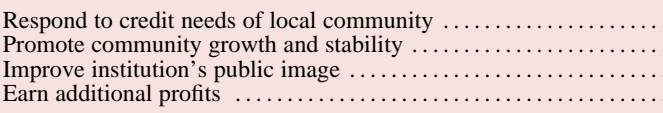 & $\begin{array}{l}95 \\
80 \\
51 \\
46\end{array}$ & $\begin{array}{l}93 \\
74 \\
40 \\
39\end{array}$ & $\begin{array}{l}99 \\
92 \\
76 \\
65\end{array}$ & $\begin{array}{l}96 \\
91 \\
65 \\
42\end{array}$ \\
\hline 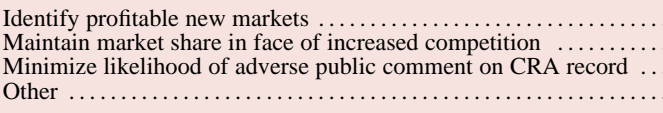 & $\begin{array}{r}44 \\
42 \\
31 \\
3\end{array}$ & $\begin{array}{r}41 \\
31 \\
22 \\
3\end{array}$ & $\begin{array}{r}53 \\
61 \\
47 \\
4\end{array}$ & $\begin{array}{r}41 \\
64 \\
52 \\
3\end{array}$ \\
\hline 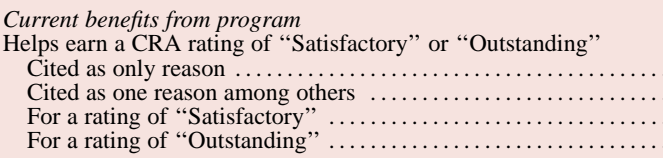 & $\begin{array}{l}1 \\
80 \\
41 \\
53\end{array}$ & $\begin{array}{l}1 \\
80 \\
44 \\
45\end{array}$ & $\begin{array}{r}0 \\
86 \\
43 \\
71\end{array}$ & $\begin{array}{r}2 \\
73 \\
17 \\
66\end{array}$ \\
\hline 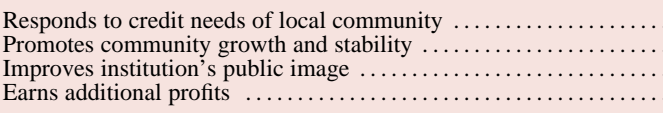 & $\begin{array}{l}94 \\
87 \\
54 \\
42\end{array}$ & $\begin{array}{l}92 \\
83 \\
47 \\
38\end{array}$ & $\begin{array}{l}99 \\
94 \\
67 \\
54\end{array}$ & $\begin{array}{l}94 \\
94 \\
66 \\
35\end{array}$ \\
\hline $\begin{array}{l}\text { Identifies profitable new markets } \\
\text { Maintains market share in face of increased competition } \\
\text { Minimizes likelihood of adverse public comment on CRA record } \\
\text { Other }\end{array}$ & $\begin{array}{r}37 \\
50 \\
38 \\
1\end{array}$ & $\begin{array}{r}33 \\
38 \\
30 \\
1\end{array}$ & $\begin{array}{r}45 \\
73 \\
54 \\
2\end{array}$ & $\begin{array}{r}42 \\
71 \\
52 \\
0\end{array}$ \\
\hline
\end{tabular}

Note. See notes to table 2, except that here components do not sum to 100 because respondents could give more than one answer.

Although their roles vary across programs, third parties conduct a wide range of activities that contribute to the implementation of CRA special lending programs, including activities that reduce the costs and risks of default that banking institutions might otherwise incur in extending credit to the populations served by the special programs. The most frequently cited activities were providing grants for down payments or other purposes, providing pre-loan education or counseling to loan applicants, and helping lenders identify prospective borrowers. Large banking institutions were more likely than smaller institutions to use third-party services for applicant screen- ing and for grants to cover the loan down payment, while smaller institutions were more likely to use third-party underwriting services, credit guarantees, and subsidies to borrowers for fees they incur in obtaining mortgage credit.

Apart from the efforts of third parties, many features of CRA special mortgage programs directly involved the banking institutions themselves (table 6). The most frequently mentioned were more flexible underwriting criteria, a second review of loan applicants to determine qualifications, special outreach and marketing activities, waived or reduced fees, pre-loan education or counseling to applicants,

4. CRA special mortgage programs, grouped by size of banking institution and distributed by targeted market, 1999 Percentage of programs

\begin{tabular}{|c|c|c|c|c|}
\hline \multirow{2}{*}{ Target } & \multirow{2}{*}{$\begin{array}{l}\text { All-institutions } \\
\text { estimate }\end{array}$} & \multicolumn{3}{|c|}{ Size of banking institution (assets, in millions of dollars) } \\
\hline & & $950-4,999$ & $5,000-29,999$ & 30,000 or more \\
\hline $\begin{array}{l}\text { Lower-income targets } \\
\text { Neighborhoods } \ldots \ldots \ldots \ldots \ldots \\
\text { Borrowers } \ldots \ldots \ldots \ldots \ldots \ldots \\
\text { Neighborhoods and borrowers }\end{array}$ & $\begin{array}{r}6 \\
22 \\
69\end{array}$ & $\begin{array}{r}6 \\
24 \\
66\end{array}$ & $\begin{array}{r}4 \\
18 \\
76\end{array}$ & $\begin{array}{r}8 \\
17 \\
76\end{array}$ \\
\hline Other $\ldots \ldots \ldots \ldots \ldots \ldots \ldots \ldots$ & 3 & 4 & 2 & 0 \\
\hline Total & 100 & 100 & 100 & 100 \\
\hline
\end{tabular}

Note. See notes to table 2. 
5. Third-party involvement in CRA special mortgage programs, by size of banking institution, 1999 Percentage of programs

\begin{tabular}{|c|c|c|c|c|}
\hline \multirow{2}{*}{ Third-party types and activities } & \multirow{2}{*}{$\begin{array}{l}\text { All-institutions } \\
\text { estimate }\end{array}$} & \multicolumn{3}{|c|}{ Size of banking institution (assets, in millions of dollars) } \\
\hline & & $950-4,999$ & $5,000-29,999$ & 30,000 or more \\
\hline Any $\ldots \ldots$ & 76 & 72 & 87 & 73 \\
\hline 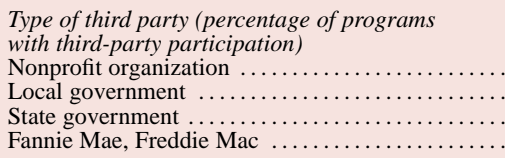 & $\begin{array}{l}47 \\
35 \\
30 \\
24\end{array}$ & $\begin{array}{l}46 \\
30 \\
19 \\
13\end{array}$ & $\begin{array}{l}40 \\
43 \\
47 \\
43\end{array}$ & $\begin{array}{l}71 \\
46 \\
48 \\
33\end{array}$ \\
\hline 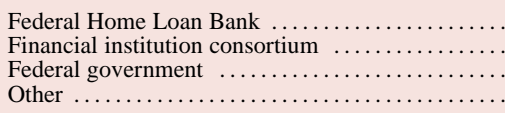 & $\begin{array}{r}22 \\
21 \\
17 \\
2\end{array}$ & $\begin{array}{r}20 \\
21 \\
13 \\
3\end{array}$ & $\begin{array}{r}25 \\
19 \\
21 \\
0\end{array}$ & $\begin{array}{r}23 \\
25 \\
31 \\
2\end{array}$ \\
\hline 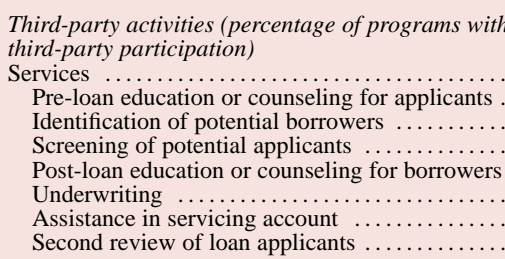 & $\begin{array}{r}70 \\
57 \\
49 \\
33 \\
28 \\
16 \\
15 \\
3\end{array}$ & $\begin{array}{r}73 \\
60 \\
47 \\
34 \\
27 \\
23 \\
17 \\
4\end{array}$ & $\begin{array}{r}63 \\
47 \\
49 \\
26 \\
25 \\
6 \\
10 \\
0\end{array}$ & $\begin{array}{r}75 \\
67 \\
63 \\
40 \\
38 \\
6 \\
15 \\
6\end{array}$ \\
\hline 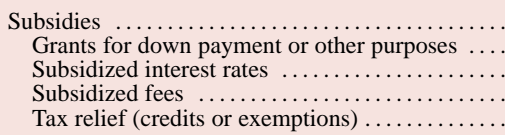 & $\begin{array}{r}71 \\
60 \\
27 \\
24 \\
3\end{array}$ & $\begin{array}{r}70 \\
59 \\
24 \\
27 \\
1\end{array}$ & $\begin{array}{r}69 \\
58 \\
36 \\
21 \\
3\end{array}$ & $\begin{array}{l}81 \\
71 \\
19 \\
15 \\
17\end{array}$ \\
\hline $\begin{array}{l}\text { Assumption of risk } \ldots \ldots \ldots \ldots \ldots \ldots \ldots \ldots \ldots \\
\text { Subordinate mortgages } \ldots \ldots \ldots \ldots \ldots \ldots \ldots \ldots \ldots \\
\text { Credit guarantees } \ldots \ldots \ldots \ldots \ldots \ldots \ldots \ldots \ldots \ldots \ldots \ldots\end{array}$ & $\begin{array}{l}49 \\
36 \\
16\end{array}$ & $\begin{array}{l}49 \\
33 \\
20\end{array}$ & $\begin{array}{r}42 \\
35 \\
8\end{array}$ & $\begin{array}{r}65 \\
60 \\
8\end{array}$ \\
\hline $\begin{array}{l}\text { Miscellaneous } \ldots \ldots \ldots \ldots \ldots \ldots \ldots \ldots \ldots \\
\text { Purchase of broker loans } \ldots \ldots \ldots \ldots \ldots \ldots \ldots \ldots \ldots \ldots \ldots\end{array}$ & $\begin{array}{r}13 \\
12 \\
1\end{array}$ & $\begin{array}{l}6 \\
4 \\
1\end{array}$ & $\begin{array}{r}29 \\
28 \\
1\end{array}$ & $\begin{array}{r}17 \\
17 \\
0\end{array}$ \\
\hline
\end{tabular}

Note. See notes to table 2, except that here components do not sum to 100 because respondents could give more than one answer.

and reduced interest rates. The proportion of CRA special mortgage programs that offered any given feature varied somewhat across institution size classes, although the smallest institutions were less likely to conduct the two major services-type activities-special outreach and marketing and preloan education or counseling - and less likely to conduct a second review of applicants.

The alteration of customary underwriting standards by banking institutions was a part of a large majority (83 percent) of special mortgage programs. The most frequently cited underwriting variances offered were lower down payments; the acceptance of alternative measures of credit quality, such as rent and utility payment histories, in lieu of more traditional measures of credit risk; lower cash reserve requirements; and higher debt-to-income ratios. A large proportion of programs (58 percent) also allowed additional flexibility when reviewing an applicant's employment history. The opportunity for borrowers to qualify for credit using these additional underwriting flexibilities suggests that loans made under CRA special mortgage programs may have elevated rates of delinquency and default. Banking institutions may offset these apparent additional risks through steps they often take in conjunction with these underwriting variances, such as pre-loan education and counseling and enhanced monitoring of borrower payment patterns.

\section{PERFORMANCE AND PROFITABILITY OF CRA SPECIAL MORTGAGE PROGRAMS}

Performance and profitability are important issues to consider in evaluating the long-term viability of CRA special mortgage programs and the effect of these programs on the financial condition of the banking institutions that offer them.

\section{Performance}

To assess the performance of CRA special mortgage programs, the survey focused on delinquency rates and net charge-off rates, which are closely related to default rates (see box "Measures of Performance"). The survey used two measures of delinquency-the 
6. Program features and underwriting variances provided by institutions in their CRA special mortgage programs, by size of banking institution, 1999

Percentage of programs

\begin{tabular}{|c|c|c|c|c|}
\hline \multirow{2}{*}{ Feature or underwriting variance } & \multirow{2}{*}{$\begin{array}{l}\text { All-institutions } \\
\text { estimate }\end{array}$} & \multicolumn{3}{|c|}{ Size of banking institution (assets, in millions of dollars) } \\
\hline & & $950-4,999$ & $5,000-29,999$ & 30,000 or more \\
\hline \multicolumn{5}{|l|}{ Program feature ${ }^{1}$} \\
\hline 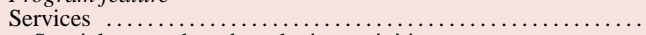 & 67 & 58 & 86 & 83 \\
\hline Special outreach and marketing activities $\ldots . . . .$. & 52 & 40 & 74 & 79 \\
\hline $\begin{array}{l}\text { Pre-loan education or counseling for applicants... } \\
\text {. }\end{array}$ & 45 & 38 & 60 & 52 \\
\hline Post-loan education or counseling for borrowers & 8 & 9 & 5 & 11 \\
\hline 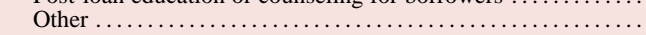 & 3 & 4 & 1 & 5 \\
\hline Subsidies $\ldots \ldots \ldots \ldots \ldots$ & 72 & 74 & 65 & 80 \\
\hline Waived or reduced fees & 51 & 56 & 40 & 46 \\
\hline Reduced interest rates $\ldots \ldots \ldots \ldots \ldots \ldots \ldots \ldots$ & 41 & 45 & 30 & 41 \\
\hline Waived PMI (private mortgage insurance) & 30 & 33 & 21 & 39 \\
\hline Grants for down payment or other purposes ............. & 23 & 24 & 19 & 24 \\
\hline Special financial incentives to loan officers or brokers .... & 21 & 15 & 28 & 46 \\
\hline Altered terms $\ldots \ldots \ldots \ldots \ldots \ldots$ & 88 & 89 & 84 & 88 \\
\hline More flexible underwriting criteria & 76 & 80 & 65 & 80 \\
\hline Second review of loan applicants . & 55 & 48 & 68 & 70 \\
\hline Longer term of loan .............. & 10 & 12 & 10 & 0 \\
\hline \multicolumn{5}{|l|}{ Underwriting variances ${ }^{2}$} \\
\hline \multirow{2}{*}{\multicolumn{5}{|c|}{ Variances (as a percentage of programs with any variances) }} \\
\hline & & & & \\
\hline 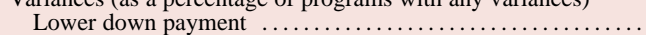 & 85 & 86 & 83 & 88 \\
\hline Alternative measures of credit quality (such as rent payments) & 79 & 76 & 88 & 82 \\
\hline 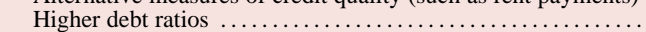 & 77 & 83 & 59 & 70 \\
\hline Lower cash reserve requirement ...................... & 72 & 70 & 72 & 78 \\
\hline More flexible requirements for employment history . & 58 & 58 & 57 & 58 \\
\hline Lower standards for credit history $\ldots \ldots \ldots \ldots \ldots \ldots$ & 45 & 52 & 22 & 38 \\
\hline \multicolumn{5}{|l|}{$\begin{array}{l}\text { Provisions waived or reduced } \\
\text { Plon }\end{array}$} \\
\hline PMI or credit guarantee .... & 40 & 43 & 26 & 45 \\
\hline Collateral ............. & 2 & 2 & 2 & 3 \\
\hline Compensating balances & 8 & 7 & 9 & 12 \\
\hline Less documentation ..... & 14 & 16 & 5 & 20 \\
\hline Other $\ldots \ldots \ldots \ldots \ldots$ & 4 & 4 & 3 & 3 \\
\hline
\end{tabular}

Note. See notes to table 2, except that here components do not sum to 100 because respondents could give more than one answer

1. Responses to part B, question 14, "What special features or services does your banking institution provide in connection with the program?"

percentage of loan dollars 30-89 days past due and the percentage of loan dollars 90 days or more past due or nonaccruing - that, like net charge-off rates, are commonly used in the industry and are regularly tracked and disclosed in regulatory reports filed by banking institutions. ${ }^{10}$ Both delinquency measures are calculated as of December 31, 1999, and the net charge-off rate is calculated over the calendar year 1999.

The relative performance of CRA special mortgage programs varied with the measure of performance considered. For delinquencies, survey responses indicated that, on average, CRA special mortgage programs had lower rates than those for overall CRArelated home purchase and refinance lending but higher rates than those for an institution's total home purchase and refinance lending (table 7). For example, the mean rate for loans that were delinquent 90 or more days or nonaccruing was 1.00 percent for CRA special mortgage programs, 1.42 percent for

10. For commercial banks and some savings associations, it is the Report of Condition and Income (Call Report), and for the remaining savings associations, the Thrift Institution Financial Report.
2. Responses to part B, question 17, "Are your banking institution's customary underwriting standards ... altered under [the] program?"

overall CRA-related home purchase and refinance lending, and 0.78 percent for total home purchase and refinance lending.

On the other hand, CRA special mortgage programs performed better than total home purchase and refinance lending when performance was assessed using median values. For example, the median per program rate for loans that were delinquent 90 or more days or nonaccruing was 0.07 percent for CRA special mortgage programs and 0.53 percent for total home purchase and refinance lending.

For net charge-offs, the zero rate for more than half of the CRA special mortgage programs could possibly reflect the relative newness of many of the programs as well as the influence of a number of other factors, including more intensive screening of prospective borrowers, sometimes by third parties, greater efforts to work with delinquent borrowers, and policies encouraging increased forbearance for such programs.

The performance of these programs appears to vary with the asset size of the banking institution operating the program. On average, CRA special mortgage programs at large banking institutions had 
7. Performance of CRA special mortgage programs, by size of banking institution, 1999 Percentage of loan dollars per program

\begin{tabular}{|c|c|c|c|c|c|c|}
\hline \multirow{2}{*}{ Program performance measure } & \multirow{2}{*}{$\begin{array}{l}\text { All-institutions } \\
\text { estimate }\end{array}$} & \multicolumn{3}{|c|}{ Size of banking institution (assets, in millions of dollars) } & \multicolumn{2}{|c|}{ Memo: All-institutions estimate ${ }^{1}$} \\
\hline & & $950-4,999$ & $5,000-29,999$ & 30,000 or more & $\begin{array}{l}\text { All CRA-related } \\
\text { mortgage loans }{ }^{2}\end{array}$ & $\begin{array}{l}\text { All mortgage } \\
\text { loans }^{3}\end{array}$ \\
\hline \multicolumn{7}{|l|}{ Delinquencies ${ }^{4}$} \\
\hline Mean ....... & 1.94 & 1.31 & 3.04 & 3.07 & 2.95 & 1.86 \\
\hline Median...$\ldots \ldots \ldots \ldots \ldots$ & .50 & .00 & 1.88 & 2.01 & 2.40 & 1.44 \\
\hline \multicolumn{7}{|l|}{90 or more days or nonaccruing } \\
\hline 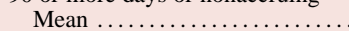 & 1.00 & .59 & 1.72 & 1.70 & 1.42 & .78 \\
\hline Median...$\ldots \ldots \ldots \ldots \ldots$ & .07 & .00 & .91 & 1.06 & .90 & .53 \\
\hline \multicolumn{7}{|l|}{ Net charge-offs ${ }^{5}$} \\
\hline Mean ........... & .19 & .09 & .41 & .36 & .23 & .14 \\
\hline Median & .00 & .00 & .00 & .05 & .05 & .02 \\
\hline
\end{tabular}

Note. Results are for loans held in institution's portfolio. See also notes to table 2 and text box "Measures of Performance."

1. Only institutions that reported performance of their CRA special mortgage program loans as well as of all their CRA-related mortgage loans and of their total mortgage loans. The weights for calculating the all-institutions estimate here are the number of CRA special mortgage programs offered by the respondents.

2. All of institution's CRA-related home purchase and refinance loans, whether or not part of a CRA special lending program.

3. All of institution's home purchase and refinance loans, whether or not CRA-related.

4. At year-end 1999

5. Total net charge-offs of program loan dollars during 1999 divided by average program loan dollars outstanding during 1999.

higher delinquency and charge-off rates than programs at smaller institutions. For example, at yearend 1999, the mean 30-89 day delinquency rate for the CRA special mortgage programs of large banking institutions was 3.07 percent, while the mean for smaller institutions was 1.31 percent.

\section{Profitability}

The survey sought information on the profitability of CRA special mortgage programs using return on equity (ROE) as the preferred measure of profitability (see box "Measuring Profitability"). Discussions

8. CRA special mortgage programs, grouped by size of banking institution and distributed by profitability category of program, 1999

Percentage of programs

\begin{tabular}{|c|c|c|c|c|c|c|}
\hline \multirow{2}{*}{ Program profitability measure } & \multirow{2}{*}{$\begin{array}{l}\text { All-institutions } \\
\text { estimate }\end{array}$} & \multicolumn{3}{|c|}{ Size of banking institution (assets, in millions of dollars) } & \multicolumn{2}{|c|}{ Мемо: All-institutions estimate ${ }^{1}$} \\
\hline & & $950-4,999$ & $5,000-29,999$ & 30,000 or more & $\begin{array}{l}\text { All CRA-related } \\
\text { mortgage loans }\end{array}$ & $\begin{array}{l}\text { All mortgage } \\
\text { loans }^{3}\end{array}$ \\
\hline \multicolumn{7}{|l|}{$\begin{array}{l}\text { CRA special mortgage } \\
\text { programs alone }\end{array}$} \\
\hline Profitable $\ldots \ldots \ldots \ldots \ldots \ldots$ & 29 & 34 & 19 & 20 & 37 & 61 \\
\hline Marginally profitable $\ldots \ldots \ldots \ldots$ & 35 & 38 & 35 & 20 & 40 & 33 \\
\hline Break-even ............ & 14 & 18 & 5 & 15 & 1 & 7 \\
\hline Marginally unprofitable .. & 15 & 7 & 29 & 29 & 18 & 0 \\
\hline Unprofitable ............ & 7 & 4 & 12 & 16 & 4 & 0 \\
\hline Total ..... & 100 & 100 & 100 & 100 & 100 & 100 \\
\hline \multicolumn{7}{|l|}{$\begin{array}{l}\text { Relative to all CRA-related } \\
\text { mortgage loans }{ }^{4}\end{array}$} \\
\hline Lower . .............. & 32 & 31 & 33 & 38 & & $\ldots$ \\
\hline Same ...... & 50 & 55 & 43 & 42 & $\ldots$ & $\ldots$ \\
\hline Higher ......... & 17 & 15 & 24 & 20 & $\ldots$ & $\cdots$ \\
\hline Total ........... & 100 & 100 & 100 & 100 & $\ldots$ & $\cdots$ \\
\hline \multicolumn{7}{|l|}{ Relative to all mortgage loans 5} \\
\hline Lower ................... & 59 & 49 & 77 & 78 & $\ldots$ & $\ldots$ \\
\hline Same $\ldots \ldots \ldots \ldots \ldots$ & 36 & 51 & 4 & 18 & $\ldots$ & $\ldots$ \\
\hline Higher .......... & 5 & 0 & 20 & 4 & $\cdots$ & $\ldots$ \\
\hline Total $\ldots$ & 100 & 100 & 100 & 100 & $\cdots$ & $\ldots$ \\
\hline
\end{tabular}

NotE. Results are for estimates of 1999 profitability. See also notes to table 2 and text box "Measuring Profitability."

1. Only institutions that reported profitability of CRA special mortgage program loans as well as of all their CRA-related mortgage loans and of their total mortgage loans. The weights for calculating the all-institutions estimate here are the number of CRA special mortgage programs offered by the respondents.

2. All of institution's CRA-related home purchase and refinance loans, whether or not part of a CRA special lending program.

3. All of institution's home purchase and refinance loans, whether or not

4. Data derived from comparing the profitability category ("profitable" through "unprofitable") in which respondents placed CRA special mortgage program loans with the category in which they placed all of their CRA-related home purchase and refinance loans.

5. Data derived from comparing the profitability category ("profitable" through "unprofitable") in which respondents placed CRA special mortgage program loans with the category in which they placed all of their home purchase and refinance loans.

.. Not applicable. CRA-related. 
with banking institutions in advance of the survey suggested that some of them might have difficulty calculating an ROE for individual loan programs. Consequently, the survey also collected detailed qualitative information on profitability as well: Banking institutions were asked if each individual CRA special mortgage program was "profitable," "marginally profitable," "break even," "marginally unprofitable," or "unprofitable." The same question was asked for overall CRA-related home purchase and refinance lending and total home purchase and refinance lending. Only the qualitative data are provided here because they were in fact far more frequently reported than were the quantitative data.

According to respondents, the majority (64 percent) of CRA special mortgage programs were either profitable or marginally profitable in 1999 (table 8). Twenty-two percent of the programs were considered either marginally unprofitable or unprofitable. Experience varies across reporting banking institutions grouped by asset size. Compared with large and medium-sized institutions, small institutions (assets of between $\$ 0.950$ billion and $\$ 4.999$ billion) reported that a higher percentage of their CRA mortgage programs were either profitable or marginally profitable and that a lower percentage were either marginally unprofitable or unprofitable in 1999. For example, small institutions reported that 72 percent of their CRA special lending programs were either profitable or marginally profitable; large institutions reported that only 40 percent of their programs were either profitable or marginally profitable.

This pattern-smaller institutions being more likely to report that their programs were profitable-is consistent with the broader pattern observed for all CRA-related mortgage lending and could be the result of a number of factors. As one example, the pattern is consistent with the view that smaller banking institutions have better knowledge of their local markets and more familiarity with local borrowers, which could result in less risky loan portfolios derived from better assessments of the risks

\section{Measures of Performance}

Given a definition of performance in terms of delinquency or default, one can measure performance in either of two ways. One method is to consider performance at the loan level by calculating the percentage of loans that are delinquent or in default. The second method is dollar-based: The dollars or costs (in dollars) associated with delinquent or defaulted loans are summed and compared with the total dollars of loans outstanding. This article uses the dollarbased measure of performance.

For the definition of loan performance, many people are familiar with the terms "delinquency" and "default." Delinquency occurs when a borrower fails to make a scheduled payment on a loan in a timely manner and in full. Because loan payments are typically due monthly, the lending industry customarily categorizes delinquent loans as either $30,60,90$, or 120 or more days late depending on the length of time the oldest unpaid loan payment has been overdue. ${ }^{1}$

Technically, default occurs at the same time as delinquency; that is, a loan is in default as soon as the borrower misses a scheduled payment. However, the term "default" is not generally used this way in the mortgage market, where it has, instead, a variety of other definitions. Among them are these four:

1. For purposes of reporting on delinquency experience in the Report of Condition and Income (for commercial banks) and the Thrift Institution Financial Report (for savings associations), institutions typically group delinquent loans into three broad categories: $30-89$ days past due and still accruing interest, 90 days or more delinquent and still accruing interest, and nonaccruing.
- A lender forecloses on the property to gain title to the asset securing the loan

- The borrower chooses to give the lender title to the property securing the loan "in lieu of foreclosure"

- The borrower sells the property securing the loan obligation and makes less than full payment on the obligation

- The lender renegotiates or modifies the terms of the loan and forgives some or all of the delinquent principal and interest payments. Loan modifications may take many forms, including a change in the interest rate on the loan, an extension of the length of the loan, and an adjustment of the principal balance due.

Regardless of the definition of default used, a dollarbased measure of it could be computed, but the measure would not take into account the losses associated with default, which may be more or less than the loan amount. The actual losses are the unpaid principal and interest plus ancillary out-of-pocket costs, such as those of collection, less any amounts recovered.

As a consequence, a related dollar-based measure of default - net charge-offs-is often used instead. For a given loan, the net charge-off is the total dollars owed at default (including the ancillary out-of-pocket costs) minus any subsequent recoveries. The institution-based net charge-off rate is calculated by summing its loan-level net charge-offs over a period of time (a year, for example) and dividing this amount by the average outstanding loan balances (including delinquent loans) over the period. In this article, the institutional net charge-off rate is used as the measure of default. 
associated with prospective borrowers. As a second example, the pattern is also consistent with the view that smaller institutions are less likely to be involved in mergers and hence are less subject to some of the lending incentives associated with the CRA. In this view, smaller institutions would be less inclined to provide services that adversely affect profitability. The accuracy of conjectures such as these is unknown.

The profitability of CRA special mortgage programs can also be gauged using two types of comparisons with the profitability of two broader groups of loans examined in the analysis of performance: all CRA-related home purchase and refinance lending and total home purchase and refinance lending.

The first type of comparison looks at the profitability distribution of CRA special mortgage programs against the profitability distribution of each of the two broader groups of loans. This comparison finds that while 64 percent of CRA special mortgage programs were reported to be at least marginally profitable (table 8), 77 percent of all CRA-related mort-

\section{Measuring Profitability}

Measuring the profitability of lending activities offers special challenges. First, the profit on a loan or program can be calculated in various ways. For the survey, profit from a lending activity was measured using a comprehensive definition that included all "revenues and costs associated with overhead, origination, and servicing costs; pricing; delinquency, default and losses; prepayment; loan sales and purchases; and related customer account business." Although overhead was not defined, it was intended to include the costs of permanent and working capital (sometimes referred to as a hurdle rate).

Total dollars of profit may not be a meaningful measure of profitability, as programs may differ in size, for example. Therefore, profitability is typically expressed as a rate, with return on equity (ROE) and return on assets (ROA) both commonly used. Calculating the ROE or the ROA for a program requires the allocation of equity or assets, respectively, to it. The ROA is commonly used because it can often be more easily calculated for a given point in time. However, the ROA cannot be used to compare programs among institutions that have varying propensities for selling their loans. For example, a banking institution that sells most of the loans it originates, and thus has few assets, may misleadingly appear to be extraordinarily profitable when measured using the ROA. Thus, comparing the ROA across programs in which loans are sold at different rates can be misleading. Consequently, ROE was selected as the more appropriate measure of profitability to be used in the survey. gage lending and 94 percent of overall home purchase and refinance lending programs were reported to be at least marginally profitable (table 8 , memo).

A second approach compares the 1999 profitability of CRA special mortgage programs with that of other loan groups within each institution. That is, survey responses by an individual institution regarding the profitability of each loan group were compared and rank ordered. If the responses indicated that the profitability category (profitable, marginally profitable, break even, marginally unprofitable, unprofitable) of two groups was the same, their relative profitability was considered to be equal. If an institution's responses placed two loan groups in different profitability categories, then relative profitability was judged based on which group was placed in the higher profitability category.

The results indicate that respondents placed 50 percent of their CRA special mortgage programs in the same profitability category as their overall CRArelated home purchase and refinance lending. Of the comparisons revealing a difference between CRA special mortgage programs and overall CRA-related home purchase and refinance lending, roughly twice the percentage of CRA special mortgage programs were placed in a lower profitability category than were placed in a higher profitability category (32 percent versus 17 percent).

Differences are more prominent when comparisons are made between the profitability of CRA special mortgage programs and total home purchase and refinance lending. Here, nearly 60 percent of CRA special mortgage programs were placed in a lower profitability category.

Performance and profitability are generally thought to be positively correlated, and thus one would expect that rank orderings of groups of loans by the two criteria should be similar. But in the case of CRA special mortgage programs, the similarities did not hold. For profitability, CRA special mortgage programs tended to be less profitable than CRA-related and total home purchase and refinance lending. Conversely, for performance, CRA special mortgage programs performed better on average than overall CRArelated home purchase and refinance lending and only slightly worse than overall lending by most measures of performance. This apparent inconsistency may be a consequence of additional, perhaps costly, steps that institutions take as a part of their CRA special mortgage programs to identify and work with potential borrowers both before and after the loan is extended. These efforts, which can include enhanced marketing, counseling, and more intensive monitoring of loan payments, may result in better 
9. Selected characteristics of CRA special mortgage programs, grouped by size of banking institution and size of program and distributed by profitability category of program, 1999

A. All banking institutions

Percentage of programs

\begin{tabular}{|c|c|c|c|c|c|c|c|c|c|}
\hline \multirow{2}{*}{ Characteristic } & \multicolumn{3}{|c|}{ All programs } & \multicolumn{3}{|c|}{ Small programs } & \multicolumn{3}{|c|}{ Large programs } \\
\hline & Profitable & Break-even & Unprofitable & Profitable & Break-even & Unprofitable & Profitable & Break-even & Unprofitable \\
\hline All programs & 64 & 14 & 22 & 67 & 16 & 17 & 60 & 11 & 29 \\
\hline $\begin{array}{l}\text { Reason for program establishment or } \\
\text { benefit of program } \\
\text { Help earn a CRA rating of } \\
\text { "Satisfactory" or }\end{array}$ & & & & & & & & & \\
\hline $\begin{array}{l}\text { "Outstanding" ................. } \\
\text { Respond to community credit needs } \\
\text { or promote community growth }\end{array}$ & 64 & 15 & 20 & 65 & 18 & 16 & 63 & 11 & 26 \\
\hline and stability $\ldots \ldots \ldots \ldots \ldots \ldots$ & 63 & 14 & 23 & 66 & 17 & 17 & 59 & 11 & 30 \\
\hline Improve institution's public image $\ldots$ & 61 & 10 & 29 & 64 & 10 & 26 & 57 & 10 & 33 \\
\hline profitable new markets ........... & 74 & 7 & 19 & 86 & 3 & 10 & 64 & 10 & 25 \\
\hline $\begin{array}{l}\text { Maintain market share in face of } \\
\text { increased competition }{ }^{1} \ldots \text {. }\end{array}$ & 63 & 12 & 25 & 73 & 12 & 15 & 55 & 12 & 33 \\
\hline $\begin{array}{l}\text { Minimize likelihood of adverse } \\
\text { public comment on } \\
\text { CRA record } \ldots \ldots \ldots \ldots \ldots . .\end{array}$ & 60 & 10 & 30 & 65 & 6 & 29 & 55 & 14 & 32 \\
\hline 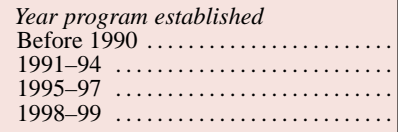 & $\begin{array}{l}38 \\
59 \\
63 \\
75\end{array}$ & $\begin{array}{l}22 \\
11 \\
17 \\
15\end{array}$ & $\begin{array}{l}40 \\
31 \\
20 \\
10\end{array}$ & $\begin{array}{l}* \\
67 \\
57 \\
80\end{array}$ & $\begin{array}{c}* \\
12 \\
21 \\
14\end{array}$ & $\begin{array}{r}* \\
22 \\
22 \\
6\end{array}$ & $\begin{array}{c}44 \\
45 \\
69 \\
*\end{array}$ & $\begin{array}{r}10 \\
9 \\
12 \\
*\end{array}$ & $\begin{array}{l}46 \\
46 \\
18 \\
*\end{array}$ \\
\hline $\begin{array}{l}\text { Program features and } \\
\text { underwriting variances } \\
\text { provided by bank }{ }^{2}\end{array}$ & & & & & & & & & \\
\hline Services $\ldots \ldots \ldots \ldots$. & 65 & 12 & 23 & 72 & 14 & 14 & 58 & 10 & 32 \\
\hline Subsidies $\ldots \ldots \ldots \ldots$ & 61 & 16 & 23 & 62 & 17 & 21 & 59 & 15 & 25 \\
\hline Altered terms ............... & 66 & 13 & 21 & 72 & 14 & 15 & 60 & 12 & 28 \\
\hline $\begin{array}{l}\text { Underwriting variances } \\
\text { Changes in required } \\
\text { down payment, } \\
\text { debt ratios, } \\
\text { and cash reserves } \ldots \ldots \text {. }\end{array}$ & 64 & 15 & 22 & 64 & 18 & 19 & 64 & 11 & 26 \\
\hline $\begin{array}{l}\text { Altered standards for credit } \\
\text { quality and employment } \\
\text { history } \ldots \ldots \ldots \ldots \ldots \ldots \ldots\end{array}$ & 66 & 12 & 22 & 67 & 11 & 21 & 65 & 12 & 24 \\
\hline $\begin{array}{l}\text { Waivers or reductions in } \\
\text { security requirements } \ldots \ldots \ldots\end{array}$ & 58 & 17 & 25 & 61 & 18 & 21 & 52 & 15 & 33 \\
\hline Multiple variances.$\ldots \ldots \ldots \ldots \ldots$ & 64 & 14 & 22 & 68 & 16 & 16 & 60 & 11 & 29 \\
\hline $\begin{array}{l}\text { Note. Covers each institution's estin } \\
\text { argest programs. For the small programs } \\
2 \text { million; for the large programs, orig } \\
\text { maller banking institutions (tables } 9 . \mathrm{B} \\
\text { ess than } \$ 30 \text { billion; for larger instituti }\end{array}$ & $\begin{array}{l}\text { ate of } 199 \\
1999 \text { loan o } \\
\text { ations wer } \\
\text { nd } 9 . \mathrm{C}) \text {, y } \\
\text { ns, assets }\end{array}$ & $\begin{array}{l}\text { profitability } \\
\text { ginations wer } \\
\text { at least } \$ 2 \mathrm{~m} \\
\text { r-end } 1999 \text { a } \\
\text { re at least } \$\end{array}$ & $\begin{array}{l}\text { of its five } \\
\text { re less than } \\
\text { nillion. For } \\
\text { assets were } \\
30 \text { billion. }\end{array}$ & $\begin{array}{l}\text { ginally ur } \\
\text { profitabili } \\
\text { 1. Also } \\
\text { 2. For } \\
\text { * Data }\end{array}$ & $\begin{array}{l}\text { rofitable." S } \\
\text { categories } \mathrm{m} \\
\text { includes reaso } \\
\text { etailed list, se } \\
\text { eceived on fiv }\end{array}$ & $\begin{array}{l}\text { ee also notes } \\
\text { nay not sum to } \\
\text { ons reported un } \\
\text { ee table } 6 \text {. } \\
\text { ve or fewer pro }\end{array}$ & $\begin{array}{l}\text { to table } 2 \text {; } \\
100 \text { because } \\
\text { der "other" } \\
\text { grams. }\end{array}$ & $\begin{array}{l}\text { alues for each } \\
\text { of rounding. } \\
\text { n the survey. }\end{array}$ & h set of thre \\
\hline
\end{tabular}

loan performance but may also lower the profitability of the loans.

\section{RELATIONSHIP BETWEEN PROGRAM FEATURES AND PROGRAM PROFITABILITY}

The features of CRA special mortgage programs, how banking institutions deliver the services associated with them, and the characteristics of the banking institutions themselves all may influence the profitability of these programs. The previous analysis indicated that in 1999 the profitability of CRA special mortgage programs varied significantly with the size of the banking institution that operated them. Further analysis (not shown) suggests that the profitability of these programs also varied with program size, mea- sured by dollars of 1999 loan originations. Consequently, the following analysis of the relationship between program features and profitability categorizes programs by their size (large and small) and by the size of the banking institution that instituted the program. ${ }^{11}$ Too few small programs were reported on by large institutions to support analysis, so figures for this subcategory are not reported here; the small number of such programs likely reflects the focus of the survey, which asked banking institutions to report detailed information on only their five largest programs.

11. Large programs had loan originations in 1999 exceeding $\$ 2$ million; small programs had 1999 originations of less than $\$ 2$ million. 


\section{9.-Continued}

B. Smaller institutions

Percentage of programs

\begin{tabular}{|c|c|c|c|c|c|c|c|c|c|}
\hline \multirow{2}{*}{ Characteristic } & \multicolumn{3}{|c|}{ All programs } & \multicolumn{3}{|c|}{ Small programs } & \multicolumn{3}{|c|}{ Large programs } \\
\hline & Profitable & Break-even & Unprofitable & Profitable & Break-even & Unprofitable & Profitable & Break-even & Unprofitable \\
\hline All programs & 67 & 14 & 20 & 67 & 17 & 17 & 66 & 10 & 24 \\
\hline $\begin{array}{l}\text { Reason for program establishment or } \\
\text { benefit of program } \\
\text { Help earn a CRA rating of } \\
\text { "Satisfactory", or } \\
\text { "Outstanding" ............... }\end{array}$ & 68 & 15 & 17 & 65 & 18 & 16 & 72 & 9 & 19 \\
\hline $\begin{array}{l}\text { Respond to community credit needs } \\
\text { or promote community growth }\end{array}$ & & & & & & & 12 & y & 19 \\
\hline and stability $\ldots \ldots \ldots \ldots \ldots$ & 66 & 14 & 20 & 66 & 17 & 17 & 64 & 10 & 26 \\
\hline Improve institution's public image & 64 & 9 & 27 & 64 & 10 & 26 & 64 & 7 & 29 \\
\hline $\begin{array}{l}\text { profitable new markets ........ }\end{array}$ & 77 & 6 & 18 & 87 & 3 & 9 & 67 & 8 & 25 \\
\hline $\begin{array}{l}\text { Maintain market share in face of } \\
\text { increased competition ..... } \\
\text { Minimize likelihood of adverse }\end{array}$ & 67 & 11 & 22 & 72 & 12 & 15 & 60 & 10 & 30 \\
\hline $\begin{array}{l}\text { public comment on } \\
\text { CRA record } \ldots \ldots \ldots \ldots\end{array}$ & 65 & 9 & 27 & 65 & 6 & 29 & 64 & 12 & 24 \\
\hline Year program established & & & & & & & & & \\
\hline Before $1990 \ldots \ldots \ldots \ldots$ & 46 & 16 & 38 & $*$ & * & * & 55 & 0 & 45 \\
\hline $1991-94 \ldots$. & 62 & 10 & 29 & 66 & 12 & 22 & 52 & 5 & 44 \\
\hline 1995-97 & 64 & 18 & 19 & 57 & 22 & 21 & 72 & 13 & 15 \\
\hline 1998-99 & 77 & 16 & 7 & 80 & 14 & 6 & 67 & 22 & 10 \\
\hline $\begin{array}{l}\text { Program features and } \\
\text { underwriting variances } \\
\text { provided by bank }\end{array}$ & & & & & & & & & \\
\hline Services .............. & 68 & 12 & 21 & 72 & 15 & 14 & 63 & 8 & 28 \\
\hline Subsidies $\ldots \ldots \ldots \ldots$ & 64 & 16 & 20 & 62 & 17 & 21 & 67 & 14 & 19 \\
\hline Altered terms ............. & 70 & 13 & 18 & 71 & 14 & 15 & 67 & 11 & 22 \\
\hline $\begin{array}{l}\text { Underwriting variances } \\
\text { Changes in required } \\
\text { down payment, } \\
\text { debt ratios, } \\
\text { and cash reserves. }\end{array}$ & 67 & 15 & 19 & 63 & 18 & 10 & 73 & 11 & 22 \\
\hline $\begin{array}{r}\text { Altered standards for credit } \\
\text { quality and employment }\end{array}$ & or & 15 & 19 & & & & & & \\
\hline history $\ldots \ldots \ldots \ldots \ldots \ldots$ & 70 & 11 & 19 & 67 & 11 & 21 & 76 & 10 & 14 \\
\hline $\begin{array}{l}\text { Waivers or reductions in } \\
\text { security requirements }\end{array}$ & 63 & 16 & 21 & 61 & 18 & 21 & 70 & 9 & 21 \\
\hline Multiple variances ........ & 67 & 14 & 20 & 68 & 16 & 16 & 65 & 10 & 25 \\
\hline
\end{tabular}

Note. See notes to table 9.A.

Once program size and banking institution size are taken into account, the profitability of CRA special mortgage programs does not appear to have varied significantly with the reason for which a program was established or the benefit afforded by a program (tables 9.A, B, and C). For almost every reason cited by banking institutions for creating a program and for almost every benefit, the proportion of programs reported to be profitable and unprofitable is quite similar to that of the "all programs" category (first line of tables). The comparison holds even for programs that were specifically established to achieve a "Satisfactory" or "Outstanding" CRA rating.

Programs established as a source of additional profits or to identify profitable new markets are an exception to the pattern. For each combination of program size and institution size, except large programs at smaller banking institutions (table 9.B), the proportion of programs established to be a profit source that is reported to have been profitable was substantially higher than the proportion in the all-programs category. Another exception is small CRA special mortgage programs at smaller banking institutions (table 9.B) that were established, at least in part, to improve an institution's public image or to minimize the likelihood of adverse public comment on the institution's CRA record; these programs were more likely to be unprofitable than the all-programs category for smaller institutions.

The profitability of CRA special mortgage programs appears to vary with the age of the program, with newer programs generally being more profitable than older programs.

As noted earlier, CRA special mortgage programs carry a wide range of features and underwriting variances (table 6). For the most part, no close relationship appears to exist between the features or 
9. Selected characteristics of CRA special mortgage programs, grouped by size of banking institution and size of program and distributed by profitability category of program, 1999-Continued

C. Large institutions

Percentage of programs

\begin{tabular}{|c|c|c|c|c|c|c|}
\hline \multirow{2}{*}{ Characteristic } & \multicolumn{3}{|c|}{ All programs } & \multicolumn{3}{|c|}{ Large programs } \\
\hline & Profitable & Break-even & Unprofitable & Profitable & Break-even & Unprofitable \\
\hline All programs & 40 & 15 & 45 & 38 & 15 & 46 \\
\hline $\begin{array}{l}\text { Reason for program establishment or benefit } \\
\text { of program }\end{array}$ & & & & & & \\
\hline $\begin{array}{l}\text { "Outstanding" ................................... } \\
\text { Respond to community credit needs or }\end{array}$ & 35 & 16 & 49 & 32 & 17 & 51 \\
\hline promote community growth and stability & 41 & 15 & 44 & 39 & 16 & 45 \\
\hline Improve institution's public image $\ldots \ldots \ldots \ldots$. & 38 & 18 & 45 & 38 & 18 & 45 \\
\hline $\begin{array}{l}\text { Earn additional profits or identify } \\
\text { profitable new markets .............. }\end{array}$ & 53 & 18 & 28 & 55 & 19 & 26 \\
\hline $\begin{array}{l}\text { Maintain market share in face of increased } \\
\text { competition } \ldots \ldots \ldots \ldots \ldots \ldots \ldots \ldots \ldots \ldots\end{array}$ & 41 & 18 & 41 & 38 & 19 & 43 \\
\hline $\begin{array}{l}\text { Minimize likelihood of adverse public comment } \\
\text { on CRA record }\end{array}$ & 31 & 17 & 52 & 31 & 17 & 52 \\
\hline Year program established & & & & & & \\
\hline Before $1990 \ldots \ldots \ldots \ldots$ & 0 & 50 & 50 & 0 & 50 & 50 \\
\hline $1991-94 \quad \ldots \ldots \ldots \ldots$ & 29 & 21 & 50 & 23 & 23 & 54 \\
\hline 1995-97 & 58 & 8 & 33 & 59 & 9 & 32 \\
\hline 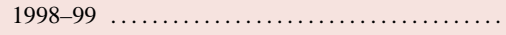 & * & * & $*$ & * & * & * \\
\hline $\begin{array}{l}\text { Program features and underwriting variances } \\
\text { provided by bank }\end{array}$ & & & & & & \\
\hline Services & 42 & 16 & 42 & 40 & 16 & 44 \\
\hline Subsidies $\ldots \ldots \ldots \ldots$ & 39 & 17 & 43 & 37 & 19 & 44 \\
\hline Altered terms ............ & 40 & 13 & 48 & 37 & 13 & 50 \\
\hline Underwriting variances & & & & & & \\
\hline $\begin{array}{l}\text { Changes in required down payment, debt ratios, } \\
\text { and cash reserves }\end{array}$ & 42 & 15 & 44 & 39 & 15 & 46 \\
\hline $\begin{array}{l}\text { Altered standards for credit quality and } \\
\text { employment history } \ldots \ldots \ldots \ldots \ldots \ldots \ldots \ldots\end{array}$ & 40 & 17 & 43 & 39 & 17 & 44 \\
\hline Waivers or reductions in security requirements & 21 & 25 & 54 & 19 & 26 & 56 \\
\hline Multiple variances $\ldots \ldots \ldots \ldots \ldots \ldots \ldots \ldots \ldots \ldots \ldots \ldots \ldots \ldots \ldots$ & 42 & 15 & 43 & 40 & 16 & 44 \\
\hline
\end{tabular}

NotE. See notes to table 9.A.

variances and program profitability (tables 9.A, B, and $\mathrm{C}$ ). Even when a banking institution offered some form of subsidy, such as a reduced interest rate or a fee waiver or reduction, CRA special mortgage programs generally were not reported to be more unprofitable than the all-programs category for the same size category of program and institution. These service categories reflect, however, only the existence of a feature or subsidy and not necessarily its amount or extent. The survey collected no further information on these items.

Responses indicated that the participation of third parties in CRA special mortgage programs was sometimes related to program profitability, depending on the type and number of third parties involved and the nature of their role in the program (tables 10.A and B). Overall, among programs with a third party, 67 percent were profitable compared with 54 percent of programs with no third party. But CRA special mortgage programs at large banking institutions (table 10.A) were less likely to be profitable (more likely to be unprofitable) when a third party was involved in the program than when one was not. By contrast, programs were more frequently profitable when programs with third parties were conducted by smaller banking institutions (table 10.A) and when third parties participated in small programs (table $10 . B)$, although the frequency of unprofitability was about the same for both groups.

Programs that exclusively involved government entities as third parties generally appeared to be more profitable than other programs. Overall, 75 percent of CRA special mortgage programs that involved only a government entity were reported to be profitable (table 10.A), compared with 64 percent of all CRA special mortgage programs. Although half of such programs at large banks were reported to be unprofitable, large banks reported only a small number of third-party programs that exclusively involved a government entity (data not shown).

The results for other types of third-party involvement are not consistent. For example, large programs (table 10.B) that exclusively involved a governmentsponsored entity (Fannie Mae, Freddie Mac, or the Federal Home Loan Banks) were less likely to be reported as profitable than large programs considered as a group (22 percent versus 60 percent). However, large programs that involved a government- 
10. Third-party involvement in CRA special mortgage programs, grouped by size of banking institution and size of program and distributed by profitability category of program, 1999

A. By size of banking institution

Percentage of programs

\begin{tabular}{|c|c|c|c|c|c|c|c|c|c|}
\hline \multirow{2}{*}{ Third-party types and activities } & \multicolumn{3}{|c|}{ All-institutions estimate } & \multicolumn{3}{|c|}{ Smaller } & \multicolumn{3}{|c|}{ Large } \\
\hline & Profitable & Break-even & Unprofitable & Profitable & Break-even & Unprofitable & Profitable & Break-even & Unprofitable \\
\hline All programs & 64 & 14 & 22 & 67 & 14 & 20 & 40 & 15 & 45 \\
\hline Presence of third parties & & & & & & & & & \\
\hline Yes $\ldots \ldots \ldots \ldots \ldots \ldots \ldots$ & 67 & 9 & 23 & 71 & 9 & 20 & 37 & 15 & 48 \\
\hline No $\ldots . . \ldots \ldots \ldots \ldots . . . .$. & 54 & 26 & 19 & 54 & 28 & 18 & 56 & 11 & 33 \\
\hline \multicolumn{10}{|l|}{$\begin{array}{l}\text { Type of third party when program } \\
\text { has only one type of third party }\end{array}$} \\
\hline Any $\ldots \ldots \ldots \ldots \ldots \ldots \ldots$ & 67 & 5 & 28 & 71 & 5 & 24 & 21 & 11 & 68 \\
\hline Government & 75 & 3 & 22 & 78 & 2 & 20 & 33 & 17 & 50 \\
\hline Government-sponsored & 47 & 10 & 43 & 49 & 10 & 41 & $*$ & $*$ & $*$ \\
\hline Nonprofit ............... & 61 & 7 & 31 & 67 & 7 & 26 & 13 & 13 & 75 \\
\hline Other $\ldots \ldots \ldots \ldots \ldots \ldots \ldots$ & 91 & 0 & 9 & $*$ & $*$ & $*$ & $*$ & * & $*$ \\
\hline \multicolumn{10}{|l|}{$\begin{array}{l}\text { Type of third party when program } \\
\text { has multiple types of third parties }\end{array}$} \\
\hline Any $\ldots \ldots \ldots \ldots \ldots \ldots \ldots \ldots \ldots \ldots \ldots$ & 68 & 16 & 16 & 72 & 16 & 12 & 48 & 19 & 33 \\
\hline Government & 70 & 14 & 16 & 75 & 13 & 12 & 50 & 21 & 29 \\
\hline Government-sponsored . & 73 & 13 & 14 & 74 & 13 & 13 & 71 & 12 & 18 \\
\hline Nonprofit ............. & 67 & 16 & 17 & 73 & 17 & 11 & 48 & 16 & 36 \\
\hline Other $\ldots \ldots \ldots \ldots \ldots \ldots$ & 80 & 16 & 4 & 82 & 15 & 3 & 67 & 22 & 11 \\
\hline \multicolumn{10}{|l|}{ Third-party activities ${ }^{1}$} \\
\hline Services $\ldots \ldots \ldots \ldots \ldots \ldots$ & 67 & 9 & 24 & 71 & 9 & 20 & 37 & 15 & 48 \\
\hline Subsidies $\ldots \ldots \ldots \ldots \ldots \ldots$ & 70 & 12 & 19 & 75 & 10 & 15 & 38 & 18 & 44 \\
\hline Assumption of risk ... & 74 & 10 & 17 & 83 & 7 & 10 & 32 & 19 & 48 \\
\hline
\end{tabular}

Note. See general note to table 9.A.

1. For list, see table 5 .

* Data received on five or fewer programs.

sponsored entity as well as other third parties were more likely to be profitable than large programs considered as a group (74 percent versus 60 percent). Overall, the number of third parties involved in a
CRA special mortgage program did not seem to bear a strong relationship to program profitability.

As noted, third parties conduct a wide range of activities in support of CRA special mortgage pro-

10.-Continued

B. By size of program

Percentage of programs

\begin{tabular}{|c|c|c|c|c|c|c|c|c|c|}
\hline \multirow{2}{*}{ Third-party types and activities } & \multicolumn{3}{|c|}{ All programs } & \multicolumn{3}{|c|}{ Small } & \multicolumn{3}{|c|}{ Large } \\
\hline & Profitable & Break-even & Unprofitable & Profitable & Break-even & Unprofitable & Profitable & Break-even & Unprofitable \\
\hline All programs & 64 & 14 & 22 & 67 & 16 & 17 & 60 & 11 & 29 \\
\hline $\begin{array}{l}\text { Presence of third parties } \\
\text { Yes } \ldots \\
\text { No } \ldots\end{array}$ & $\begin{array}{l}67 \\
54\end{array}$ & $\begin{array}{r}9 \\
26\end{array}$ & $\begin{array}{l}23 \\
19\end{array}$ & $\begin{array}{l}74 \\
48\end{array}$ & $\begin{array}{r}9 \\
36\end{array}$ & $\begin{array}{l}17 \\
16\end{array}$ & $\begin{array}{l}59 \\
62\end{array}$ & $\begin{array}{r}9 \\
15\end{array}$ & $\begin{array}{l}32 \\
23\end{array}$ \\
\hline $\begin{array}{l}\text { Type of third party when program } \\
\text { has only one type of third party }\end{array}$ & & & & & & & & & \\
\hline $\begin{array}{c}\text { Any } \ldots \ldots \ldots \ldots \ldots \ldots \\
\text { Government } \ldots \ldots \ldots \ldots \ldots \ldots \\
\text { Government-sponsored } \ldots \ldots \ldots \\
\text { Nonprofit } \ldots \ldots \ldots \ldots \ldots \ldots \ldots \ldots \ldots \\
\text { Other } \ldots \ldots \ldots \ldots \ldots \ldots \ldots \ldots \ldots \ldots \\
\end{array}$ & $\begin{array}{l}67 \\
75 \\
47 \\
61 \\
91\end{array}$ & $\begin{array}{r}5 \\
3 \\
10 \\
7 \\
0\end{array}$ & $\begin{array}{r}28 \\
22 \\
43 \\
31 \\
9\end{array}$ & $\begin{array}{l}75 \\
76 \\
64 \\
72 \\
*\end{array}$ & $\begin{array}{l}3 \\
0 \\
0 \\
8 \\
*\end{array}$ & $\begin{array}{l}22 \\
24 \\
36 \\
20 \\
*\end{array}$ & $\begin{array}{l}54 \\
74 \\
22 \\
33 \\
*\end{array}$ & $\begin{array}{r}9 \\
6 \\
24 \\
5 \\
*\end{array}$ & $\begin{array}{l}37 \\
20 \\
54 \\
62 \\
*\end{array}$ \\
\hline $\begin{array}{l}\text { Type of third party when program } \\
\text { has multiple types of third parties }\end{array}$ & & & & & & & & & \\
\hline $\begin{array}{c}\text { Any } \ldots \ldots \ldots \ldots \ldots \ldots \ldots \\
\text { Government } \ldots \ldots \ldots \ldots \ldots \ldots \\
\text { Government-sponsored } \ldots \ldots \ldots \\
\text { Nonprofit } \ldots \ldots \ldots \ldots \ldots \ldots \ldots \ldots \ldots \\
\text { Other } \ldots \ldots \ldots \ldots \ldots \ldots \ldots \ldots \ldots \ldots \ldots \\
\end{array}$ & $\begin{array}{l}68 \\
70 \\
73 \\
67 \\
80\end{array}$ & $\begin{array}{l}16 \\
14 \\
13 \\
16 \\
16\end{array}$ & $\begin{array}{r}16 \\
16 \\
14 \\
17 \\
4\end{array}$ & $\begin{array}{l}70 \\
73 \\
72 \\
67 \\
71\end{array}$ & $\begin{array}{l}24 \\
20 \\
22 \\
33 \\
24\end{array}$ & $\begin{array}{l}6 \\
7 \\
7 \\
0 \\
5\end{array}$ & $\begin{array}{l}66 \\
67 \\
74 \\
66 \\
91\end{array}$ & $\begin{array}{r}10 \\
10 \\
8 \\
9 \\
6\end{array}$ & $\begin{array}{r}24 \\
23 \\
18 \\
25 \\
3\end{array}$ \\
\hline $\begin{array}{l}\text { Third-party activities } \\
\text { Services } \ldots \ldots \ldots \ldots \ldots \\
\text { Subsidies ............ } \\
\text { Assumption of risk } \ldots\end{array}$ & $\begin{array}{l}67 \\
70 \\
74\end{array}$ & $\begin{array}{r}9 \\
12 \\
10\end{array}$ & $\begin{array}{l}24 \\
19 \\
17\end{array}$ & $\begin{array}{l}73 \\
76 \\
83\end{array}$ & $\begin{array}{l}10 \\
11 \\
10\end{array}$ & $\begin{array}{r}17 \\
12 \\
7\end{array}$ & $\begin{array}{l}59 \\
62 \\
66\end{array}$ & $\begin{array}{r}9 \\
12 \\
9\end{array}$ & $\begin{array}{l}32 \\
26 \\
26\end{array}$ \\
\hline
\end{tabular}

Note. See notes to table 10.A. 
11. Selected characteristics of institutions with CRA special mortgage programs, grouped by size of banking institution and size of program and distributed by profitability category of program, 1999

A. All banking institutions

Percentage of programs

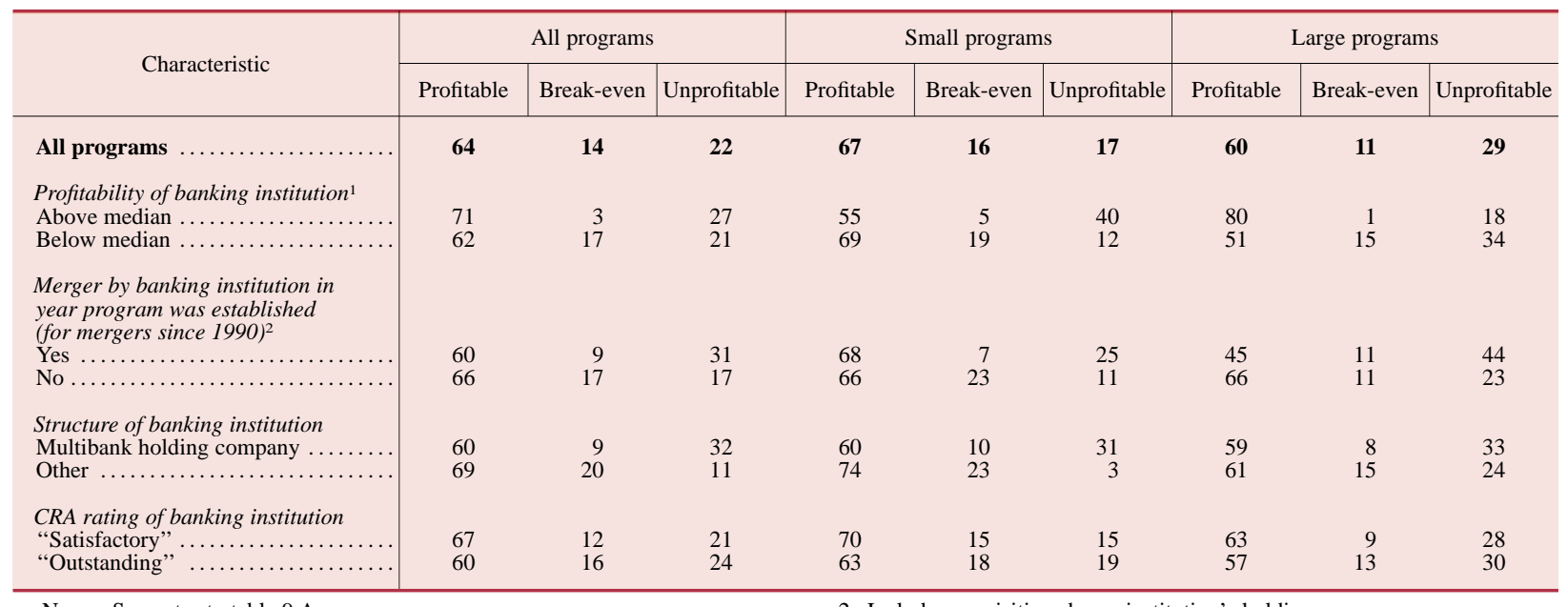

Note. See notes to table 9.A.

1. Return on equity in 1999 compared with 1999 return on equity of the

2. Includes acquisitions by an institution's holding company. 500 largest retail banking institutions.

grams (table 5), and these activities appear to be related to program profitability (tables $10 . \mathrm{A}$ and $\mathrm{B}$ ). Third-party assumption of risk was positively related to program profitability. This relationship was strongest for programs at smaller banking institutions and for small programs. For example, 83 percent of the programs at smaller banks that involve the assumption of risk by a third party were reported to be profitable (table 10.A), compared with 67 percent for all programs at such banks. Third-party provision of services and subsidies also appeared to contribute to program profitability, although these relationships were not as strong as that for the assumption of risk.

Survey results indicate that characteristics of a banking institution besides its size are related to the profitability of CRA special mortgage programs (tables 11.A, B, and C). Banking institutions with overall profitability above the median were more likely to have had large programs that were profitable than were institutions with overall profitability below the median (table 11.A). ${ }^{12}$ However, the reverse is true for small programs at smaller banking institutions (table 11.B).

Merger activity also appears to matter. In all combinations of program size and banking institution size, programs that were established in a year in which the banking institution was engaged in merg-

12. The profitability of each institution was measured as 1999 return on equity and then compared with the median 1999 return on equity of the original sample of the 500 largest retail banking institutions. ers or acquisitions were more likely to have been reported as unprofitable than programs established in years in which the banking institution did not merge.

Whether or not the banking institution is part of a multibank holding company appears to matter only for small programs at smaller banking institutions (table 11.B): Such programs at institutions that are part of multibank organizations tend to be less profitable (or more unprofitable) than programs at independent institutions.

Finally, with the exception of large programs at large banking institutions (table 11.C), a banking institution's CRA performance rating does not appear to be strongly related to program profitability. For large programs at large institutions, the percentage of programs reported as profitable for institutions with outstanding CRA ratings was the same as for institutions with satisfactory ratings. However, somewhat surprisingly, the proportion reported to have been unprofitable is much higher for those with satisfactory ratings than for those with outstanding ratings.

\section{LIMITATIONS OF THE ANALYSIS}

The survey and resulting data provide new and systematic information about the characteristics and the role of CRA special mortgage programs in the lending activities of banking institutions. In particular, the information provides opportunities to determine the factors that influence the performance 


\section{1.-Continued}

B. Smaller banking institutions

Percentage of programs

\begin{tabular}{|c|c|c|c|c|c|c|c|c|c|}
\hline \multirow{2}{*}{ Characteristic } & \multicolumn{3}{|c|}{ All programs } & \multicolumn{3}{|c|}{ Small programs } & \multicolumn{3}{|c|}{ Large programs } \\
\hline & Profitable & Break-even & Unprofitable & Profitable & Break-even & Unprofitable & Profitable & Break-even & Unprofitable \\
\hline All programs & 67 & 14 & 20 & 67 & 17 & 17 & 66 & 10 & 24 \\
\hline Profitability of banking institutio & & & & & 5 & & & & \\
\hline $\begin{array}{l}\text { Above median .... } \\
\text { Below median .... }\end{array}$ & 65 & $\begin{array}{r}2 \\
17\end{array}$ & $\begin{array}{l}26 \\
18\end{array}$ & $\begin{array}{l}57 \\
69\end{array}$ & $\begin{array}{r}5 \\
19\end{array}$ & $\begin{array}{l}39 \\
13\end{array}$ & $\begin{array}{l}84 \\
57\end{array}$ & $\begin{array}{r}0 \\
15\end{array}$ & $\begin{array}{l}16 \\
28\end{array}$ \\
\hline $\begin{array}{l}\text { Merger by banking institution } \\
\text { in year program was established } \\
\text { (for mergers since 1990) }\end{array}$ & & & & & & & & & \\
\hline Yes $\ldots \ldots \ldots \ldots \ldots \ldots$ & 65 & 8 & 27 & 68 & 7 & 24 & 55 & 11 & 34 \\
\hline No $\ldots \ldots \ldots \ldots \ldots \ldots \ldots \ldots$ & 68 & 17 & 16 & 66 & 23 & 11 & 69 & 9 & 21 \\
\hline $\begin{array}{l}\text { Structure of banking institution } \\
\text { Multibank holding company ... }\end{array}$ & 63 & 7 & 29 & 60 & 10 & 31 & 69 & 4 & 27 \\
\hline Other ................. & 70 & 21 & 10 & 74 & 23 & 3 & 63 & 16 & 21 \\
\hline CRA rating of banking institution & & & & & & & & & \\
\hline 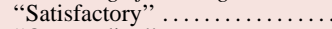 & 69 & 13 & 17 & 70 & 15 & 15 & 69 & 10 & 21 \\
\hline "Outstanding" ..... & 63 & 15 & 22 & 63 & 18 & 18 & 63 & 10 & 27 \\
\hline
\end{tabular}

Note. See notes to table 11.A.

and profitability of these programs and to better understand the role of specific program features and arrangements with third parties. However, the survey data do not address all issues in this regard, and the foregoing analysis has some important limitations.

First, by design, the survey collected detailed information on only a subset of CRA special lending programs from a fairly narrow group of lenders and programs. Only the five largest programs at each of the largest 500 retail banking institutions were covered in the survey; the characteristics and profitability of smaller programs at these institutions or of programs at other banking institutions may have differed.

Second, the survey collected performance and profitability information for 1999 only. However, 1999 lending experiences may not be representative of those of other years. For example, program performance may have been better in 1999-a year of ongoing economic expansion - than might have been expected during a year of economic weakness. In addition, some of the programs are relatively new, and their long-run performance and profitability may not be fully reflected in the survey data.

11.-Continued

C. Large banking institutions

Percentage of programs

\begin{tabular}{|c|c|c|c|c|c|c|}
\hline \multirow{2}{*}{ Characteristic } & \multicolumn{3}{|c|}{ All programs } & \multicolumn{3}{|c|}{ Large programs } \\
\hline & Profitable & Break-even & Unprofitable & Profitable & Break-even & Unprofitable \\
\hline All programs & 40 & 15 & 45 & 38 & 15 & 46 \\
\hline $\begin{array}{l}\text { Profitability of banking institution } \\
\text { Above median } \ldots \ldots \ldots \ldots \ldots \ldots \ldots \\
\text { Below median } \ldots \ldots \ldots \ldots \ldots \ldots\end{array}$ & $\begin{array}{l}55 \\
36\end{array}$ & $\begin{array}{r}9 \\
16\end{array}$ & $\begin{array}{l}36 \\
48\end{array}$ & $\begin{array}{l}60 \\
33\end{array}$ & $\begin{array}{l}10 \\
17\end{array}$ & $\begin{array}{l}30 \\
50\end{array}$ \\
\hline $\begin{array}{l}\text { Merger by banking institution } \\
\text { in year program was established } \\
\text { (for mergers since 1990) }\end{array}$ & & & & & & \\
\hline $\begin{array}{l}\text { Yes } \\
\text { No } \ldots \ldots \ldots \\
\end{array}$ & $\begin{array}{l}33 \\
48\end{array}$ & $\begin{array}{l}10 \\
20\end{array}$ & $\begin{array}{l}57 \\
32\end{array}$ & $\begin{array}{l}30 \\
48\end{array}$ & $\begin{array}{l}11 \\
20\end{array}$ & $\begin{array}{l}59 \\
32\end{array}$ \\
\hline $\begin{array}{l}\text { Structure of banking institution } \\
\text { Multibank holding company ... }\end{array}$ & 39 & 16 & 45 & 37 & 17 & 46 \\
\hline Other $\ldots \ldots \ldots \ldots \ldots \ldots \ldots$ & 45 & 9 & 45 & 45 & 9 & 45 \\
\hline $\begin{array}{l}\text { CRA rating of banking institution } \\
\text { "Satisfactory", } \ldots \ldots \ldots \ldots \ldots \\
\text { "Outstanding" } \ldots \ldots \ldots \ldots \ldots\end{array}$ & $\begin{array}{l}44 \\
37\end{array}$ & $\begin{array}{r}4 \\
23\end{array}$ & $\begin{array}{l}52 \\
40\end{array}$ & $\begin{array}{l}39 \\
38\end{array}$ & $\begin{array}{r}4 \\
24\end{array}$ & $\begin{array}{l}57 \\
38\end{array}$ \\
\hline
\end{tabular}

Note. See notes to table 11.A. 
Third, the relatively small size of the samples leaves statistics such as means imprecisely measured. These statistics should be viewed with some caution.

Fourth, the measurement of profitability poses some difficulties. Although the survey instructed respondents to measure program profitability in a comprehensive manner, there is no way of determining the extent to which all banking institutions did so. Some institutions may have included factors in their assessment of profitability that other institutions did not. Moreover, because many respondents could not provide quantitative answers regarding the profitability of their programs, qualitative answers were highlighted in this article. The quantitative distinctions underlying these qualitative responses may differ from institution to institution. These issues raise concerns regarding the degree to which responses across banking institutions can be compared.

Fifth, no definition of a "CRA special mortgage program" is universally accepted. Banking institutions may have used different criteria by which to distinguish programs or to identify those that were established to enhance CRA performance. For example, one institution might have considered a program that operates in three geographic markets to be a single program, whereas another institution might have reported that program as three separate programs distinguished by the markets in which the programs operate.

Finally, this article presents only a portion of the information that would be needed to assess the value and importance of CRA special lending programsonly those programs focused on home purchase and refinance lending are covered. Further, no information is presented on the benefits of these lending programs to local communities and borrowers or on the costs incurred by third parties in supporting such activities. Any comprehensive assessment of the full costs and benefits of these programs would need to consider these factors.

\section{SUMMARY}

This article presents new and systematic information on CRA special lending programs obtained from responses to a recent Federal Reserve survey on the performance and profitability of CRA-related lending. CRA special lending programs help an institution seek out and assist borrowers, typically among lower-income populations, and thereby help the institution meet its obligations under the CRA.

The survey, which focused on the five largest programs at each of the surveyed institutions, found that 72 percent of the programs were devoted exclusively to loans for the purchase or refinancing of one- to four-family homes. The analysis in this article concerns these programs, referred to as CRA special mortgage programs.

For most institutions, CRA special mortgage programs are relatively small. However, for about onesixth of the institutions that responded to the survey, lending under CRA special mortgage programs accounted for more than 40 percent of the institution's overall CRA-related mortgage lending.

Banking institutions cite many reasons for establishing or participating in CRA special mortgage programs. The two most frequently cited are responding to the credit needs of the local community and promoting community growth and stability. The third most frequently cited, obtaining either a "Satisfactory" or "Outstanding" CRA rating, is mentioned for about three-fourths of the programs, but it is cited as the only reason for just 1 percent of the programs.

About three-fourths of the programs involve the activities of third parties. The main activities are grants for down payments or other purposes and other services and subsidies that reduce the costs of banking institutions in extending credit to the populations served by the special programs. The programs also have a wide range of features involving the banking institutions themselves, including flexible underwriting, special outreach and marketing activities, and subsidies of fees and loan rates.

Regardless of the comparison made or the performance measure used, CRA special mortgage programs appear to perform better (that is, the loans extended through them have lower delinquency and net charge-off rates) than overall CRA-related home purchase and refinance lending. Results are less consistent when comparisons are made with an institution's total home purchase and refinance lending (both CRA-related and not CRA-related). Median delinquency and charge-off rates are lower for loans in CRA special mortgage programs than for overall mortgage lending; however, average rates for these measures of performance are all higher.

The performance of CRA special mortgage programs appears to vary with the asset size of the banking institution operating the program. On average, CRA special mortgage programs at large banking institutions (assets of $\$ 30$ billion or more) had higher delinquency and charge-off rates than programs at smaller institutions.

According to respondents, the majority of CRA special mortgage programs (64 percent) are either profitable or marginally profitable. About one-fourth of the programs are considered either marginally unprofitable or unprofitable. However, respondents 
placed three-fifths of the programs in a profitability category lower than that in which they placed overall mortgage lending. In addition, respondents placed 50 percent of the programs in the same profitability category in which they placed their overall CRA-related mortgage lending; for the other half of the programs, twice as many were placed in a lower profitability category as were placed in a higher category.
As with performance, the profitability of CRA special mortgage programs also appears to vary with an institution's size. Whether measured on an absolute or relative basis, programs of large banking institutions are more likely to be unprofitable (or to be ranked less profitable) than are programs of smaller institutions. 